Provided for non-commercial research and education use. Not for reproduction, distribution or commercial use.

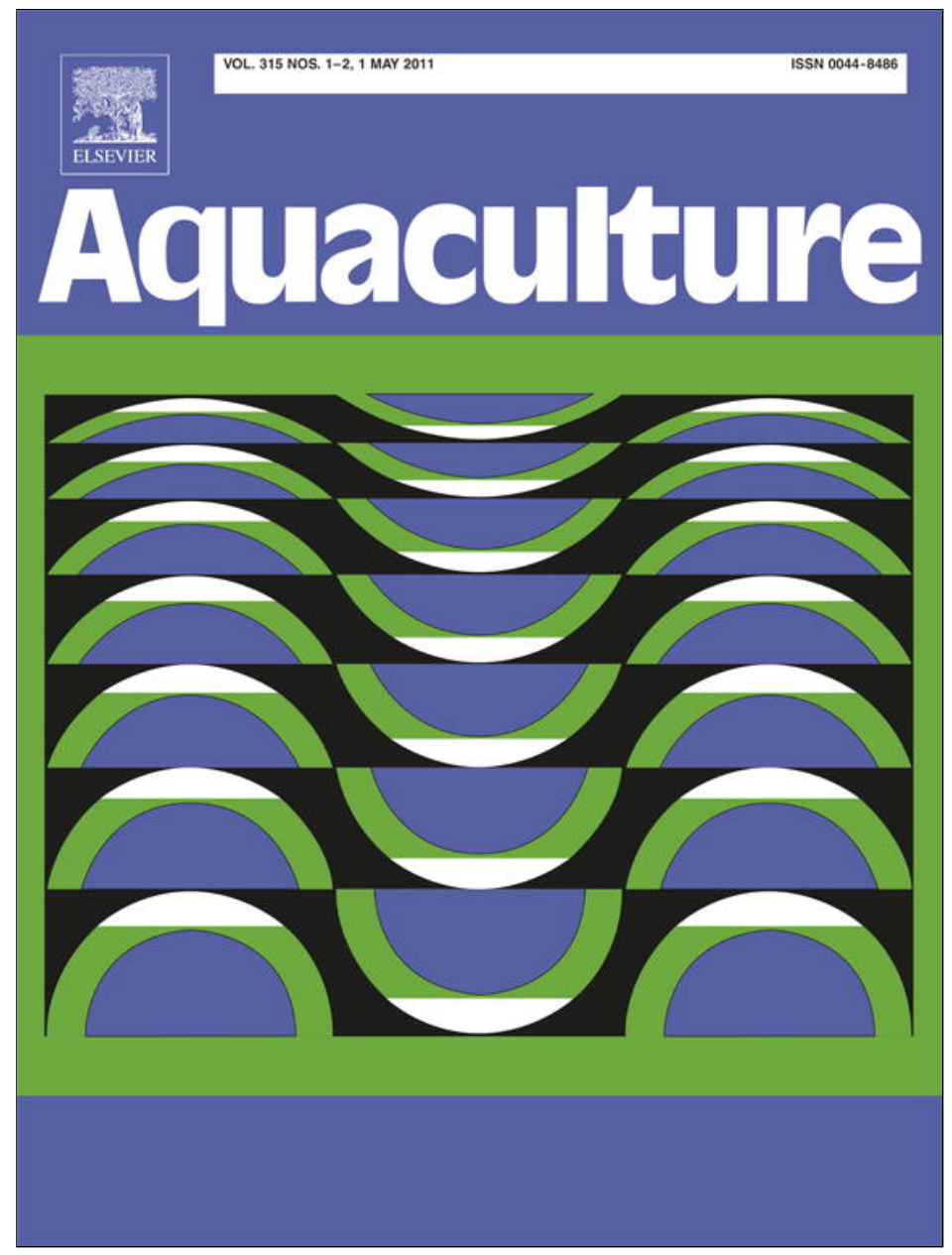

This article appeared in a journal published by Elsevier. The attached copy is furnished to the author for internal non-commercial research and education use, including for instruction at the authors institution and sharing with colleagues.

Other uses, including reproduction and distribution, or selling or licensing copies, or posting to personal, institutional or third party websites are prohibited.

In most cases authors are permitted to post their version of the article (e.g. in Word or Tex form) to their personal website or institutional repository. Authors requiring further information regarding Elsevier's archiving and manuscript policies are encouraged to visit:

http://www.elsevier.com/copyright 
Review

\title{
Characterization and modulation of gene expression and enzymatic activity of delta-6 desaturase in teleosts: A review
}

\author{
M. Vagner *, E. Santigosa \\ UMR 1067 INRA-Ifremer-Bordeaux 1, Ifremer Centre de Brest, BP 70, 29280 Plouzané, France
}

\section{A R T I C L E I N F O}

\section{Article history:}

Received 5 November 2009

Received in revised form 28 October 2010

Accepted 19 November 2010

Available online 30 November 2010

\section{Keywords:}

Delta-6 desaturase

Environmental modulation

Highly unsaturated fatty acid

Nutritional modulation

Teleosts

\begin{abstract}
A B S T R A C T
There is currently considerable interest in understanding how the biosynthetic pathways of highly unsaturated fatty acids (HUFA) are regulated in fish. The aim is to know if it is possible to replace fish oils (FO), rich in HUFA, by vegetable oils (VO), poor in HUFA and rich in their 18 carbon fatty acid precursors, in the feed of cultured fish species of commercial importance. Thus many studies have focussed on delta- 6 desaturase $(\Delta 6 \mathrm{D})$ since it is the rate-limiting enzyme involved in HUFA biosynthesis from precursors. The aims of this paper were (i) to review and compare the structure, function, and tissue distribution of the $\Delta 6 \mathrm{D}$ gene in teleosts and (ii) to review the effect of nutrition and environment on the modulation of $\Delta 6 \mathrm{D}$ gene expression and on the activity of this enzyme in teleosts. Most existing studies have clearly shown that $\Delta 6 \mathrm{D}$ is modulated by nutrition and environment in freshwater fish. This modulation allows the control of lipid metabolism and the maintenance of cell membrane functionality. $\Delta 6 \mathrm{D}$ gene expression and enzymatic activity were higher in fish fed VO diets than in those fed FO diets, irrespective of their life cycle in seawater or freshwater; this concurs with expectations regarding the compensation for HUFA deficiency in VO. However, the magnitude of these increases was not great enough to maintain HUFA tissue content. Such a decrease in tissue content may result either from competition between substrates for $\Delta 6 \mathrm{D}$ or from the inhibition of subsequent steps in HUFA biosynthesis, such as elongation or delta-5 desaturation activity. Other studies showed that $\triangle 6 \mathrm{D}$ enzyme activity is stimulated at low temperatures and low salinities, which keep cell membranes fluid. In salmonids, $\Delta 6 \mathrm{D}$ would then play an important role in the adaptation to salinity changes at parr-smolt transformation. In marine fish, similar nutritional and environmental modulations may occur, although conflicting data exist. A low expression of the $\triangle 6 \mathrm{D}$ gene or the involvement of genetic, environmental, or hormonal factors could explain why $\triangle 6 \mathrm{D}$ appears to be barely functional in marine fish. This review shows that, despite the large number of studies investigating the regulation of $\Delta 6 \mathrm{D}$, little is known about the molecular mechanisms involved. Furthermore, the nutritional and environmental regulation of other enzymes involved in HUFA biosynthesis still need to be investigated to obtain a better understanding of the regulation of HUFA biosynthetic pathways in teleosts, ultimately leading to improvements in fish production.
\end{abstract}

\section{Contents}

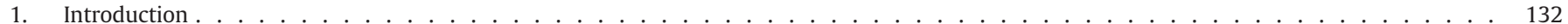

2. Characterization of $\Delta 6 \mathrm{D}$ in teleosts $\ldots \ldots \ldots \ldots$

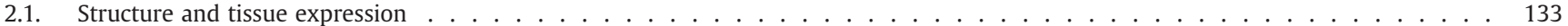

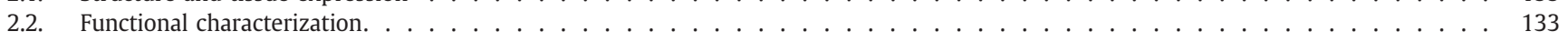

Abbreviations: CLA, conjugated linoleic acid; $\Delta 6 \mathrm{D}$, delta-6 desaturase; $\triangle 5 \mathrm{D}$, delta- 5 desaturase; DM, dry matter; FA, fatty acid; FO, fish oil; HUFA, highly unsaturated fatty acid; LA, linoleic acid; LNA, linolenic acid; PPAR, peroxisome proliferator-activated receptor; PPRE, peroxisome proliferator response element; RXR, retinoic acid X receptor; SRE, sterol regulatory element; SREBP, sterol regulatory element binding protein; VO, vegetable oil.

* Corresponding author. Institut des sciences de la mer, 310 allées des Ursulines, Rimouski (Québec) Canada G5L 3A1. Tel.: + 1418723 1986 (1709); fax: + 1418 724 1842.

E-mail address: marie.vagner@hotmail.fr (M. Vagner). 
3. Nutritional and environmental modulation of $\Delta 6 \mathrm{D}$ gene expression and enzymatic activity in teleosts . . . . . . . . . . . . . . . 134

3.1. Nutritional modulation . . . . . . . . . . . . . . . . . . . . . . . . . . . . . . . . . 134

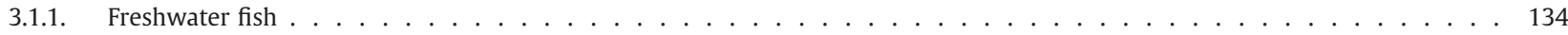

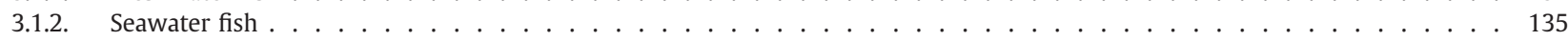

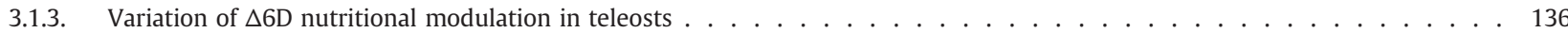

3.1.4. Mechanisms involved in the nutritional modulation of $\Delta 6 \mathrm{D} \ldots \ldots \ldots \ldots \ldots$

3.2. Environmental modulation of $\Delta 6 \mathrm{D}$ gene expression and enzymatic activity $\ldots \ldots \ldots \ldots$

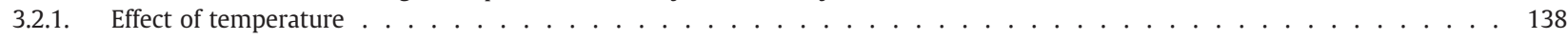

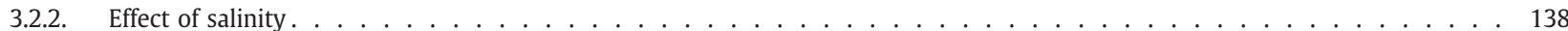

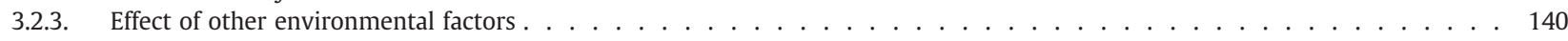

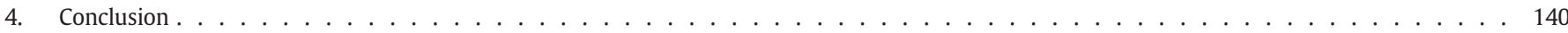

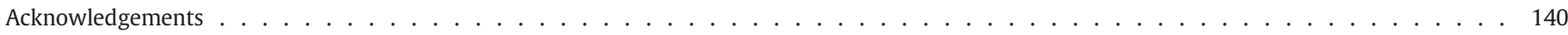

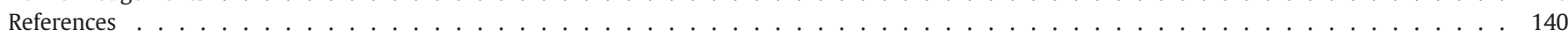

\section{Introduction}

The nutritional benefits associated with seafood are related to the presence of 20- and 22-carbon highly unsaturated fatty acids (n-3 and n-6 HUFA), such as ecosapentaenoic acid (EPA, 20:5n-3), docosahexaenoic acid (DHA, 22:6n-3), and arachidonic acid (AA, 20:4n-6) (Simopolous, 1991; Lauritzen et al., 2001; Delarue et al., 2003, 2004). These nutritional benefits are one of the reasons for the increasing worldwide demand for fish and shellfish. Because HUFAs are the major phospholipid component of cell membranes, they perform a variety of important physiological functions in vertebrates. In fish, they play key roles in ontogenesis, growth, survival, pigmentation, and resistance to stress and disease as well as in the development and functionality of the brain, vision, and nervous system (for a review, see Sargent et al., 2002).

Fish, like mammals, are unable to synthesize HUFA de novo from $n-3$ and $n-6$ series (EPA, DHA, and AA), which is not the case with the $n-9$ series HUFAs. Fish therefore require a dietary supply either of the final molecules or of their precursors (Watanabe, 1982; Sargent et al., 2002; Fig. 1). Fish are able to bioconvert 18-carbon fatty acids (C18 FA) that are found in food into $\mathrm{n}-3$ HUFAs (Sargent et al., 2002; Fig. 1). The bioconversion from linoleic acid (LA; $18: 2 n-6)$ to AA and from linolenic acid (LNA; $18: 3 n-3)$ to EPA and DHA involves desaturations at the delta- 6 and delta- 5 positions in the carbon backbone as well as an intermediate 2-carbon chain elongation step (Fig. 1). Synthesis of DHA from EPA requires the elongation of EPA to $22: 5 n-3$ and $24: 5 n-3$, which is then converted by delta- 6 desaturase ( $\triangle 6 \mathrm{D}$ ) to $24: 6 n-3$; the chain is finally shortened to DHA in peroxisomes (Buzzi et al., 1996, 1997; Sargent et al., 2002).

The $\Delta 6 \mathrm{D}$ enzyme has been widely studied in vertebrates, including fish, since it is the rate-limiting enzyme involved in HUFA biosynthesis. This enzyme is responsible for the first step of the desaturation/ elongation process in HUFA synthesis, converting LNA $(18: 3 n-3)$ and LA $(18: 2 n-6)$ to $18: 4 n-3$ and $18: 3 n-6$ respectively (Fig. 1 ; Brenner, $1981 \mathrm{a}, \mathrm{b}) . \Delta 6 \mathrm{D}$ is also involved in the synthesis of DHA $(22: 6 n-3)$

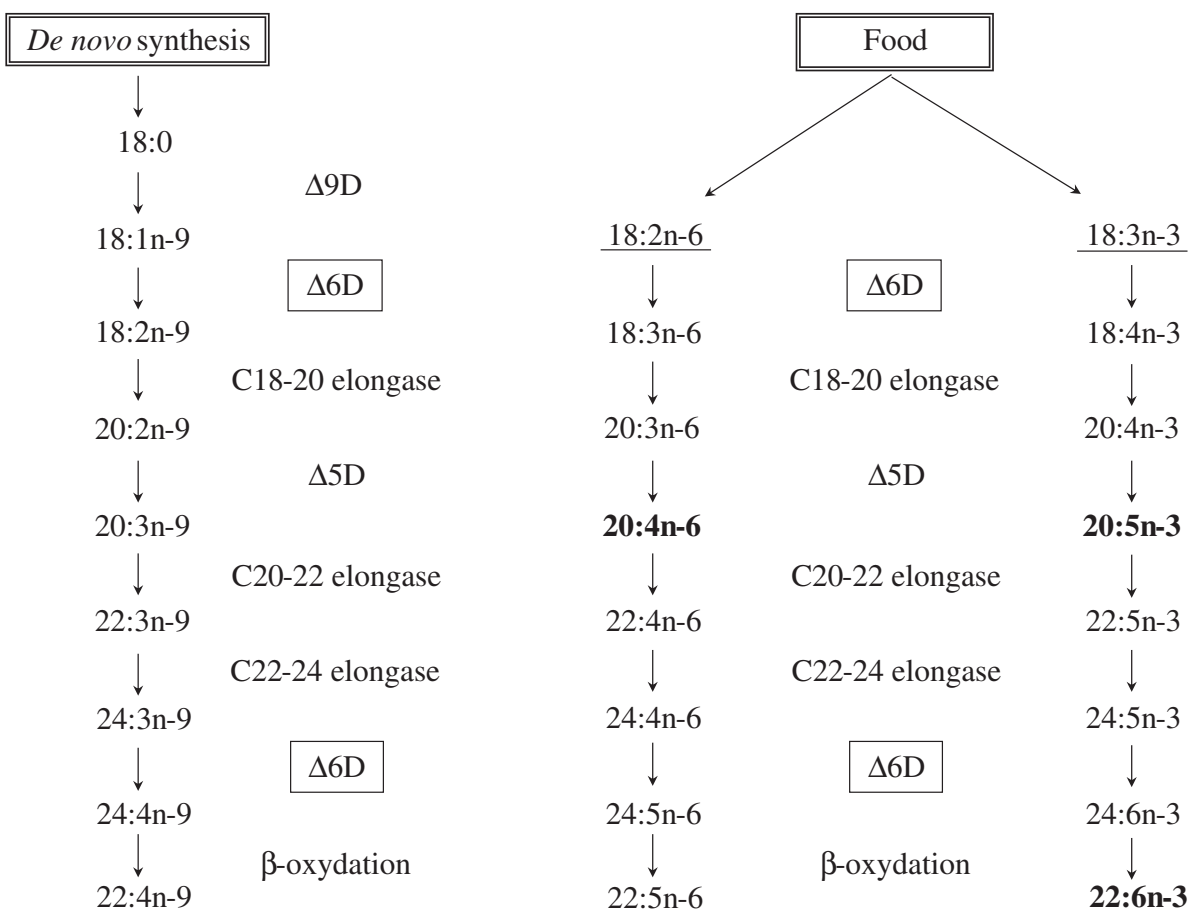

Fig. 1. HUFA biosynthesis pathways in vertebrates, including fish, and the different enzymes involved. HUFAs can be synthesised de novo ( $\mathrm{n}-9$ series), or from precursor C18 FA brought by food ( $n-3$ and $n-6$ series). Underlined C18 FA are essential in freshwater fish, while $n-6$ and $n-3$ HUFAs written in bold case are the main essential FA (AA 20:4n-6, EPA 20:5n-3 and DHA 22:6n-3) in seawater fish. This figure shows the role of the delta-6 desaturase ( $\Delta 6 \mathrm{D})$ as the rate-limiting enzyme responsible of the first step of bioconversion of C18 FAs brought by food into $n-6$ and $n-3$ HUFAs. Delta- 9 and delta- 5 are written $\Delta 9 \mathrm{D}$ and $\Delta 5 \mathrm{D}$. 
from EPA (20:5n-3). In fish, it is still unclear if one or two enzymes are involved in both reactions (Sargent et al., 2002). However, in humans (de Antueno et al., 2001) and mice (D'Andrea et al., 2002), the same enzyme serves for both reactions.

The extent to which fish can desaturate/elongate C18 FAs to HUFAs varies with species (Sargent et al., 1995, 1999, 2002; Tocher et al., 2006a,b). Freshwater species, such as carp, tilapia, and trout-which are mainly herbivorous or omnivorous-have a recognized capacity to desaturate C18 FAs from the diet (LA [18:2n-6] and LNA [18:3n-3]) into AA, EPA, and DHA (Owen et al., 1975; Henderson and Tocher, 1987; Buzzi et al., 1997; Sargent et al., 2002). In consequence, C18 FAs are essential for HUFA synthesis in freshwater fish (Fig. 1). In contrast, marine species such as turbot, seabream, and sea bass, which are carnivorous, are assumed to have a weak capacity to bioconvert C18 precursors into HUFAs and hence require the preformed HUFAs in their diet (Owen et al., 1975; Kanazawa et al., 1978; Mourente and Tocher, 1994; Sargent et al., 2002). Therefore, preformed HUFAs are themselves essential FAs for seawater fish (Fig. 1). Anadromous fish such as salmon begin their life in freshwater and migrate to the sea before returning to freshwater to breed. Their desaturase profile appears to be that of freshwater fish (Owen et al., 1975; Bell et al., 1997). Although long recognized, the reasons for the low desaturation capacity in marine species remain unclear. It could result from an adaptation to a carnivorous lifestyle (Mourente and Tocher, 1994; Henderson et al., 1995; Sargent et al., 1995), as has been suggested for terrestrial carnivores (Brenner, 1974; Rivers et al., 1975; Sinclair et al., 1979). Consumption of a piscivorous diet, naturally rich in HUFA, could have resulted in an evolutionary down-regulation of the desaturase enzymatic activity that is required for the conversion of C18 FA to HUFA (Sargent et al., 2002).

There has recently been considerable interest in the regulation of $\triangle 6 \mathrm{D}$ gene expression and its activity, with the aim of better understanding the regulation of HUFA biosynthetic pathways in commercially important cultured fish species. With the decline of traditional fisheries, aquaculture supplies an increasing proportion of fish produced for human consumption (Tidwell and Allan, 2002). Paradoxically, the predominant protein and lipid sources in the diets for aquaculture fish production come from fish meal and oil (FO) from marine fisheries. However, worldwide supplies of FO have reached their sustainable limits, forcing the feed industry to look for alternative lipid sources (Sargent and Tacon, 1999; Tacon, 2004; Pike, 2005). The only sustainable alternatives to FO are vegetable oils (VO). Therefore, there is a need to produce fish that are able to utilize and metabolize VO. Vegetable products are rich in C18 FAs but do not contain n-3 HUFAs, such as EPA and DHA. It has been widely demonstrated that the dietary FA composition is mirrored in fish tissues (Sargent et al., 2002; Bell et al., 2003a,b; Francis et al., 2007), thus the substitution of FOs by VOs in feeds would have a detrimental impact on the nutritional quality of the final farmed product (Seierstad et al., 2005). However, the lipid composition of organisms not only depends on the dietary lipid ingested, but also on the capacity of species to transform these lipids through desaturation and elongation pathways (Clandinin et al., 1983; Holman, 1986; Lands, 1991). The activity of desaturases is highly dependent upon membrane FA compositions since these are membrane-bound enzymes (Stubbs and Smith, 1984; Spector and Yorek, 1985; McMurchie, 1988; Merrill and Schroeder, 1993). Therefore, the dietary lipid composition may modulate the ability of species to desaturate FAs in order to adjust and maintain the $n-3$ HUFA content in tissues (Brenner, 1981a,b; Buzzi et al., 1996; Tocher et al., 1997). There is currently considerable interest in understanding the regulation of biosynthetic HUFA pathways in fish to determine the effectiveness with which the FAs in VOs can be utilized by commercially important cultured fish species (Mourente and Dick, 2002; Sargent et al., 2002). In this context, many studies have focussed on the modulation at both the molecular and enzy- matic levels of the $\Delta 6 \mathrm{D}$ rate-limiting enzyme involved in HUFA biosynthesis.

The aims of this paper were (i) to review and compare the structure, tissue distribution, and function of the $\triangle 6 \mathrm{D}$ gene and (ii) to review the effect of nutritional and environmental modulation on $\Delta 6 \mathrm{D}$ gene expression and $\Delta 6 \mathrm{D}$ enzymatic activity in teleosts.

\section{Characterization of $\Delta 6 \mathrm{D}$ in teleosts}

\subsection{Structure and tissue expression}

Fatty acid desaturases are membrane-bound enzymes that contain three histidine boxes and two transmembrane domains. $\Delta 5 \mathrm{D}$ and $\Delta 6 \mathrm{D}$ also present an N-terminal cytochrome b5-like domain, which includes a heme-binding motif H-P-G-G (Fig. 2). In teleosts, these regions are perfectly aligned with those of the $\Delta 5 \mathrm{D}$ and $\triangle 6 \mathrm{D}$ of other vertebrates, and desaturases in freshwater species present eight to ten additional amino acid residues in the $\mathrm{N}$-terminal extremity. Fish $\triangle 6 \mathrm{D}$ has about a $65 \%$ homology with the human homologue FADS2 (Table 1 ). Moreover, the characterized $\triangle 5 \mathrm{D}$ of Atlantic salmon (Salmo salar) and the putative $\triangle 5 \mathrm{D}$ from masu salmon (Oncorhynchus masou) are more similar to the FADS2 protein than to the human homologue FADS1, probably because a high percentage of identity ( $>90 \%$ ) exists between $\Delta 5 \mathrm{D}$ and $\Delta 6 \mathrm{D}$ of the same species (Table 1 ).

The tissue expression of fish $\Delta 6 \mathrm{D}$ has been studied in rainbow trout Oncorhyncus mykiss (Seiliez et al., 2001), Atlantic cod Gadus morhua (Tocher et al., 2006a), cobia Rachycentron canadum (Zheng et al., 2009), and sea bass Dicentrarchus labrax (González-Rovira et al., 2009). For each of these species, high levels of expression have been found in brain, liver, intestine, and kidney (Seiliez et al., 2001; Tocher et al., 2006a). González-Rovira et al. (2009) recorded the highest $\Delta 6 \mathrm{D}$ expression in the heart of sea bass. Moreover, Northern blot studies have shown the presence of highly expressed desaturase transcripts in both rainbow trout (Seiliez et al., 2001) and sea bream Sparus aurata (Seiliez et al., 2003). In each case, the size of the lower transcript corresponds to that of the desaturaselike cDNA while the physiological function of the upper transcript remains unknown.

\subsection{Functional characterization}

Many fish desaturases have been functionally characterized by heterologous expression in the yeast Saccharomyces cerevisiae (Table 1). This technique involves the amplification of the desaturase cDNA coding sequence and the subsequent ligation of the amplified product in a yeast expression vector. The $S$. cerevisiae host is then transformed with the resulting plasmid construct and the expression of the transgene is induced by galactose addition (Hastings et al., 2001). Cultures are grown in the presence of desaturase substrates, and the resultant FAs are analyzed using gas chromatography coupled with mass spectrometry. This analysis allows the identification of the specific desaturase activity when exogenous substrates are desaturated in the $\Delta 6$ and/or $\Delta 5$ positions.

The first characterized fish desaturase was the bifunctional $\Delta 5 / \Delta 6$ zebrafish enzyme (Hastings et al., 2001). Apart from this protein, which possesses the capacity to desaturate both types of substrates, other fish desaturases that have been characterized are either unifunctional (cod; Tocher et al., 2006a) or present a major desaturase activity with a residual capacity to desaturate in another position (Table 1). Even though this technique is semiquantitative because of some limitations in comparing desaturase capacities among substrates with different carbon numbers (de Antueno et al., 2001), it is possible to determine if expressed heterologous enzymes have a preference for substrates of the same chain length belonging to the $n-3$ or $n-6$ pathway. In this sense, fish desaturases preferentially 

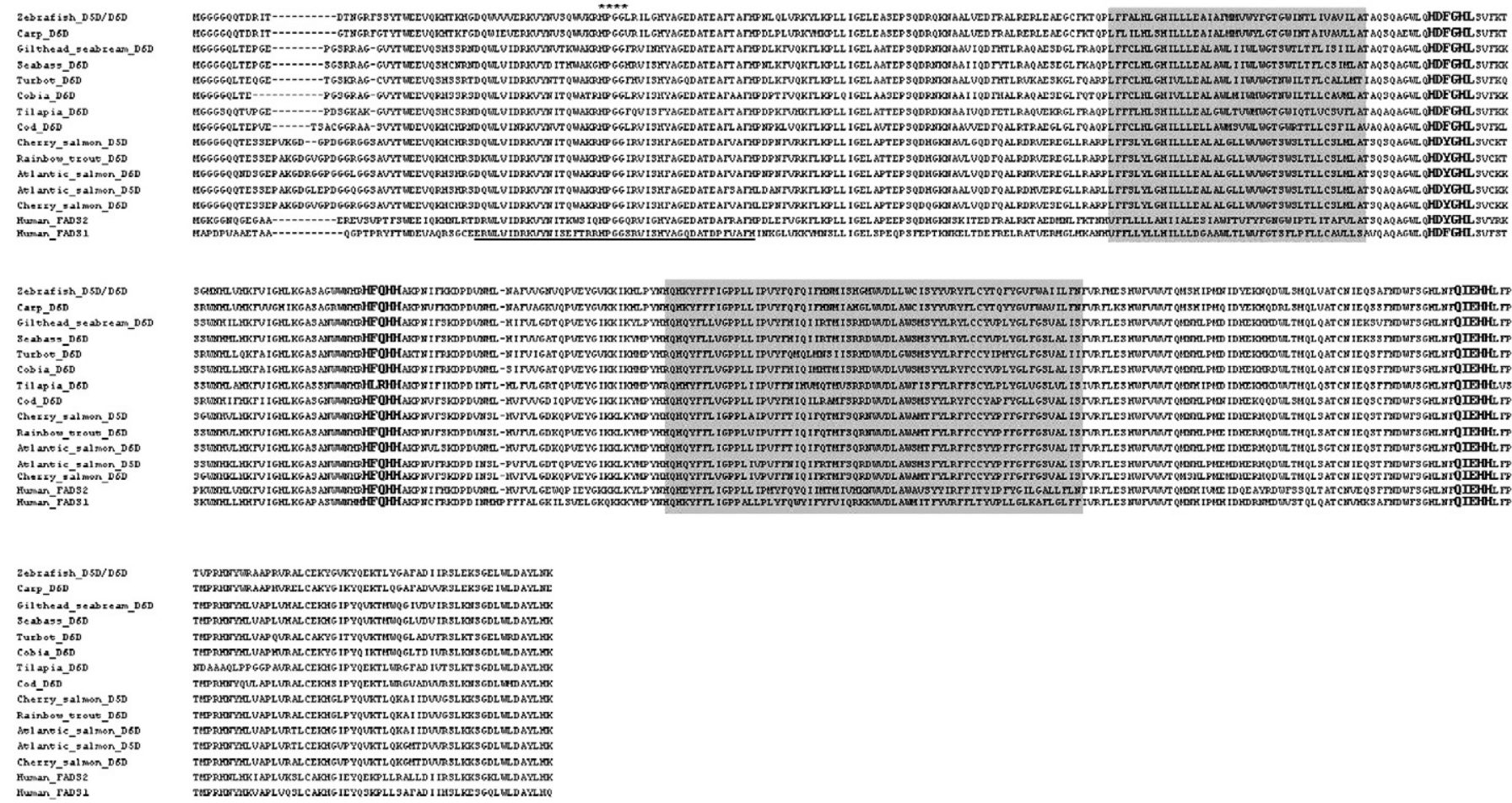

Fig. 2. Comparison of the deduced amino acid sequences of the fatty acyl desaturase from fish and human. The amino acid sequences were aligned using ClustalX. The cytochrome b5domain is underlined. Putative transmembrane domains are shown in shaded areas and the three histidine-rich regions are bolded. The asterisks indicate the heme-binding motif (HPGG).

desaturate $\mathrm{n}-3$ substrates (Table 1 ), while the functional characterization of $\triangle 6 \mathrm{D}$ from mammals, fungi, and mosses (Aki et al., 1999; Cho et al., 1999a; Kajikawa et al., 2004) has shown that these enzymes are equally active with both $n-3$ and $n-6$ substrates. The only exception is the family Primula sp., which prefers the $n-3$ substrates (Sayanova et al., 2003).

\section{Nutritional and environmental modulation of $\Delta 6 \mathrm{D}$ gene expression and enzymatic activity in teleosts}

\subsection{Nutritional modulation}

The nutritional modulation of $\Delta 6 \mathrm{D}$ has been well described in mammals (Christiansen et al., 1991; Ulmann et al., 1992; Cao et al.,
1995; Cho et al., 1999a,b). For example, diets rich in DHA reduce microsomal $\triangle 6 \mathrm{D}$ activity in rat liver (Garg et al., 1988; Christiansen et al., 1991; Ulmann et al., 1992; Cao et al., 1995). Concerning teleosts, the nutritional modulation of $\Delta 6 \mathrm{D}$ has been extensively studied to test whether desaturase activity could compensate for the reduction of tissue HUFA levels due to the inclusion of dietary VOs.

\subsubsection{Freshwater fish}

Although not always attaining statistical significance, several studies have shown that $\triangle 6 \mathrm{D}$ gene mRNA levels were higher in freshwater fish fed VOs (low HUFA content) than in those fed FOs (high HUFA content). For example, higher $\triangle 6 \mathrm{D}$ mRNA levels were measured in the liver and red muscle of Atlantic salmon fed diets in which $75 \%$ of FOs had been replaced by a blend of rapeseed, palm,

Table 1

Available $\Delta 5 \mathrm{D}$ and $\Delta 6 \mathrm{D}$ genes in fish. An asterisk denotes a desaturase sequence that has not been functionally characterized.

\begin{tabular}{|c|c|c|c|c|c|c|c|c|c|}
\hline \multirow[t]{3}{*}{ Species } & \multirow[t]{3}{*}{ Type } & \multirow{3}{*}{$\begin{array}{l}\text { GenBank } \\
\text { accession } \\
\text { number }\end{array}$} & \multirow{3}{*}{$\begin{array}{l}\text { No of amino } \\
\text { acid residues }\end{array}$} & \multicolumn{3}{|l|}{ \% Identity } & \multirow{3}{*}{$\begin{array}{l}\mathrm{n}-3 \\
\text { preference }\end{array}$} & \multirow{3}{*}{$\begin{array}{l}\text { Other desaturase } \\
\text { residual activity }\end{array}$} & \multirow[t]{3}{*}{ Functional characterization } \\
\hline & & & & \multirow[t]{2}{*}{ Intraspecific } & \multicolumn{2}{|c|}{ Human } & & & \\
\hline & & & & & FAD2 & FADS1 & & & \\
\hline Atlantic salmon (Salmo salar) & $\Delta 6$ & AY458652 & 454 & - & 65 & 54 & Yes & Yes & Zheng et al. (2005b) \\
\hline Cherry salmon (Oncorhynchus masou) & $\Delta 6^{*}$ & AB070444 & 454 & - & 63 & 53 & - & - & - \\
\hline Rainbow trout (Oncorhynchus mykiss) & $\Delta 6$ & AF30191 & 454 & - & 65 & 54 & Yes & Yes & Zheng et al. (2004a) \\
\hline Seabream (Sparus aurata) & $\Delta 6$ & AY055749 & 445 & - & 65 & 52 & Yes & Yes & Zheng et al. (2004a) \\
\hline Cod (Gadus morhua) & $\Delta 6$ & DQ054840 & 447 & - & 65 & 51 & Yes & No & Tocher et al. (2006a) \\
\hline Turbot (Scophthalmus maximus) & $\Delta 6$ & AY546094 & 445 & - & 63 & 58 & Yes & Yes & Zheng et al. (2004a) \\
\hline Cobia (Rachycentron canadum) & $\Delta 6$ & FJ440238 & 442 & - & 66 & 52 & Yes & Yes & Zheng et al. (2009) \\
\hline \multirow[t]{2}{*}{ Sea bass (Dicentrarchus labrax) } & $\Delta 6$ & EU647692 & 445 & - & 65 & 52 & - & - & Santigosa et al. (2010) \\
\hline & & & & & & & Yes & - & González-Rovira et al. (2009) \\
\hline Nile tilapia (Oreochromis niloticus) & $\Delta 6^{*}$ & AB069727 & 445 & - & $?$ & $?$ & - & - & González-Rovira et al. (2009) \\
\hline Carp (Cyprinus carpio) & $\Delta 6$ & AF309557 & 444 & - & $?$ & $?$ & Yes & Yes & Zheng et al. (2004a) \\
\hline Atlantic salmon (Salmo salar) & $\Delta 5$ & AF478472 & 454 & 91 & 64 & 54 & Yes & Yes & Hastings et al. (2005) \\
\hline Cherry salmon (Oncorhynchus masou) & $\Delta 5^{*}$ & EU098126 & 452 & 94 & 65 & 52 & - & - & - \\
\hline Zebrafish (Danio rerio) & $\Delta 5 / \Delta 6$ & AF309556 & 444 & - & 64 & 58 & Yes & Bifunctional & Hastings et al. (2001) \\
\hline
\end{tabular}


and linseed oils in a 3.7:2:1 ratio compared to fish fed HUFA-rich diets containing only FO as a lipid source (Zheng et al., 2005a,b). Similar results were obtained in salmon and rainbow trout fed diets containing linseed oil as the lipid source compared to those fed fish oil as the sole lipid source (Seiliez et al., 2001; Zheng et al., 2004b).

Moreover, replacing FOs by VOs consistently resulted in increased $\triangle 6 \mathrm{D}$ activity in freshwater fish (Bell et al., 1997, 2001, 2002; Tocher et al., 1997, 2000, 2001a,b, 2002, 2003a,b, 2004, 2006b; Zheng et al., 2005a,b); this was also seen in mammals (Brenner, 1981a,b). In Arctic charr (Salvelinus alpinus), the conversion by $\Delta 6 \mathrm{D}$ of $\left[1-{ }^{14} \mathrm{C}\right]$-labelled LA $(18: 2 n-6)$ and LNA $(18: 3 n-3)$ to $18: 3 n-6$ and $18: 4 n-3$, respectively, was higher in fish fed diets containing only VOs compared to those fed commercial diets containing FO (Olsen and Ringo, 1992). Buzzi et al. (1996) demonstrated an increase in hepatic $\Delta 6 \mathrm{D}$ activity when feeding rainbow trout on a diet containing olive oil compared to a diet containing FO. Similar results were obtained in caecal enterocytes of this species when crude palm oil replaced FO in the diet (Tocher et al., 2004; Fonseca-Madrigal et al., 2005). In Atlantic salmon, the desaturation of $18: 3 n-3$ and $18: 2 n-6$ in isolated hepatocytes was up to 2.5 -fold higher in fish fed a diet containing VO (1:1 blend of linseed and rapeseed oils) rich in $18: 2 n-6$ and 18:3n-3 compared to those fed a diet containing FO (Tocher et al., 1997). Several comparative studies on salmonids reared in freshwater showed that $\triangle 6 \mathrm{D}$ activities were up to 2.5 -fold (Bell et al., 1997), 2.4-fold (Tocher et al., 2000), and 2.8-fold (Tocher et al., 2001a) greater in fish fed VO compared to fish fed FO. More recently, a 4-fold increase in desaturation levels was measured in the caecal enterocytes of salmon fed a VO blend (1:1 rapeseed and linseed oils), than in fish fed FO (Tocher et al., 2003a). Turchini et al. (2006) demonstrated the ability of freshwater Murray cod (Maccullochella peelii peelii) to desaturate $18: 2 n-6$ and $18: 3 n-3$ when fed a diet containing either canola or linseed oil. Similar results were further obtained in this species when replacing FO with a blend of VOs (Francis et al., 2007).

Such molecular and enzymatic data from freshwater fish can be interpreted as an inhibition of $\triangle 6 \mathrm{D}$ by $\mathrm{n}-3$ HUFAs, as has been shown in mammals (Garg et al., 1988; Christiansen et al., 1991; Ulmann et al., 1992). This is in accordance with Leger et al. (1981), who first reported that a high dietary level of $22: 6 n-3$ inhibits the desaturation of both $18: 2 n-6$ and $18: 3 n-3$ in rainbow trout. On the contrary, Ruyter et al. (2000) showed that the percentage of $18: 3 n-6$-the $\Delta 6 \mathrm{D}$ desaturation product formed from $\left[1-{ }^{14} \mathrm{C}\right]$ labelled $18: 2 \mathrm{n}-6$-was twice as high in the hepatocytes of Atlantic salmon fed the FO diet than in those fed VO. This indicates that the high percentage of $22: 6 n-3$ in the FO diet did not have the expected result of radically inhibiting the desaturation of $18: 2 n-6$. This could be explained by the higher $18: 2 n-6 / 18: 3 n-3$ ratio found in the FO diet (2.8) compared to the VO diet (0.5). This higher ratio probably promoted a higher desaturation rate of $18: 2 n-6$ to $18: 3 n-6$ in fish fed the FO diet than in those fed the VO diet (Ruyter et al., 2000).

Several studies in freshwater fish reported that $\triangle 6 \mathrm{D}$ gene expression could not only be inhibited by dietary $n-3$ HUFA content but also stimulated by dietary-conjugated LA (CLA; i.e., positional and geometric isomers of LA 18:2n-6; Twibell et al., 2000; Kennedy et al., 2005 , 2006). For example, Atlantic salmon fed a diet that included $2 \%$ CLA exhibited increased $\triangle 6 \mathrm{D}$ gene expression in the liver (Kennedy et al., 2006). This was particularly evident in the diet containing only $17 \%$ FO (i.e., the low-oil diet; the high-oil diet contained 34\% FO); measurements showed a 2-fold increase in the $\triangle 6 \mathrm{D}$ mRNA level. This was correlated with an increase in HUFA synthesis in these fish and is in accordance with Twibell et al. (2000), who reported an increase in EPA and DHA in response to dietary CLA in hepatic and muscle tissues of hybrid striped bass (Morone chrysops, saxatilis). On the contrary, Leaver et al. (2006) reported that CLA had no effect on $\triangle 6 \mathrm{D}$ mRNA levels in the liver or intestine of Atlantic salmon. Moreover, Kennedy et al. (2005) reported that dietary CLA had no significant effect on either liver or muscle FA compositions in salmon. In mammals, conflicting data exist regarding CLA effects on $\triangle 6 \mathrm{D}$. Some studies have indicated a suppression of enzymatic activity after CLA feeding (Eder et al., 2002), while others showed marked induction of gene expression and enzymatic activity (Peters et al., 2001; Takahashi et al., 2003).

\subsubsection{Seawater fish}

As in freshwater, the $\triangle 6 \mathrm{D}$ mRNA levels in Atlantic salmon reared in seawater were significantly higher in fish fed VOs than in fish fed FOs (Zheng et al., 2005a,b). This molecular result was reflected by increasing levels of $20: 2 n-6$ and $20: 3 n-6$ in the liver, indicating metabolism of $18: 2 n-6$.

The nutritional modulation of $\triangle 6 \mathrm{D}$ was revealed for the first time in a strictly marine fish, gilthead seabream, by Seiliez et al. (2003). As in freshwater fish, $\Delta 6 \mathrm{D}$ gene expression in sea bream liver was higher in fish fed a HUFA-free diet (containing olive oil as the sole lipid source) than in fish fed a HUFA-rich diet (containing FO). While these authors did not measure enzyme activities, a higher production of $18: 2 n-9$ and $20: 2 n-9$ was revealed, indicating higher $\Delta 6 \mathrm{D}$ activity in fish fed HUFA-deficient diets. High levels of 18:2n-9 and 20:2n-9 were previously reported in juvenile grey mullet (initial weight $=$ $0.7 \mathrm{~g}$ ) fed on a fat-free diet for 84 days in sea water (Argyropoulou et al., 1992). Seiliez et al. (2003) also showed an 18:3n-6 increase in seabream fed a HUFA-free diet, which might be a further indication of a $\triangle 6 \mathrm{D}$ activity in these fish. Similarly, significantly higher levels of $18: 2 n-9$ and $18: 3 n-6$ and increases of more than 6 -fold in $\Delta 6 \mathrm{D}$ mRNA levels were reported in larvae of this species that had been fed diets in which FO was totally replaced by rapeseed or soybean oil (Izquierdo et al., 2008). In the same way, Vagner et al. (2007a,b, 2009) showed that $\triangle 6 \mathrm{D}$ mRNA levels were higher in sea bass larvae fed a low HUFA diet $(0.5 \%$ or $0.7 \%$ EPA + DHA, \% dry matter [DM]; FO replaced with soybean oil) compared to those fed a high HUFA diet (1.7\% or 3.7\% EPA + DHA, \% DM; only FO). This was supported by an increase in $18: 3 n-6$ content in phospholipids. Finally, a new study also showed a significantly higher $\triangle 6 \mathrm{D}$ mRNA level in the livers of sea bass fed linseed and rapeseed oils compared to the livers of fish fed FO (González-Rovira et al., 2009). None of these studies reported an increase in $18: 4 n-3$ (the desaturation product of $18: 3 n-3$ by $\Delta 6 \mathrm{D}$ ). This could be due to the relatively high level of this FA initially present in fish and to the negligible levels of $18: 3 n-3$ in VOs used in HUFAfree diets.

Unlike the results described above on studies done with other oils, González-Rovira et al. (2009) demonstrated that dietary olive oil did not significantly increase $\triangle 6 \mathrm{D}$ mRNA levels in sea bass liver compared to FO. Furthermore, contrasting results were obtained with sea bass fed two different blends of VO ( $60 \%$ substitution of FO with two blends of rapeseed, linseed, and olive oils), with the expression of the $\Delta 6 \mathrm{D}$ only significantly up-regulated in fish fed one of the blend (GonzálezRovira et al., 2009). These conflicting data obtained from sea bass could be due to the low expression of $\Delta 6 \mathrm{D}$ in the liver of this species. In addition, $\triangle 6 \mathrm{D}$ expression was not determined in other tissues following the ingestion of dietary VOs (González-Rovira et al., 2009). Previous studies have demonstrated that the inclusion of VOs did not lead to a significant increase in desaturase activity in sea bass hepatocytes (Mourente and Dick, 2002; Mourente et al., 2005b), while increased activity was reported in pyloric caecal enterocytes of sea bass fed VO blends (Mourente et al., 2005a).

Similar conflicting data have previously been reported in marine fish. Comparable $\triangle 6 \mathrm{D}$ mRNA levels were measured in the liver and intestine of adult cod ( $G$. morhua) fed diets containing VOs or FOs (Tocher et al., 2006a). This was reflected in unchanged enzyme activities in hepatocytes and enterocytes. These results suggested that the nutritional regulation of $\Delta 6 \mathrm{D}$ could vary according to the species or the developmental stage considered (Tocher et al., 2006a).

The occurrence of conflicting data in both $\triangle 6 \mathrm{D}$ gene expression and enzymatic activity in marine fish may be due to the lower 
levels of expression and enzyme activity recorded in marine fish tissues compared to freshwater fish and salmonids (Tocher et al., 2006a,b; González-Rovira et al., 2009). There may be other environmental, genetic, or hormonal factors that could explain why $\Delta 6 \mathrm{D}$ appears to be barely functional in marine fish (GonzálezRovira et al., 2009).

\subsubsection{Variation of $\Delta 6 D$ mutritional modulation in teleosts}

3.1.3.1. Variation with time: is it a long-lasting stimulation? Recent studies have attempted to discover whether the nutritional modulation of $\Delta 6 \mathrm{D}$ gene expression is a persistent adaptation at the molecular level or a transient acclimation to the nutritional environment. Vagner et al. (2007b, 2009) tested whether it was possible to modulate $\triangle 6 \mathrm{D}$ gene expression in sea bass juveniles using nutritional conditioning during the larval phase.

Larvae were fed a low $(0.5-0.8 \% \mathrm{EPA}+\mathrm{DHA}$, \% DM) or high (1.7$3.7 \% \mathrm{EPA}+\mathrm{DHA}$, \% DM) HUFA diet from mouth opening ( 6 days posthatching) to the end of the larval stage ( 45 days post-hatching). After a subsequent period ( 1 to 3 months) of feeding with a commercial diet (2.7\% EPA + DHA, \% DM), the capacity of juveniles to adapt to a HUFA-restricted diet (0.3-0.5\% EPA + DHA, \% DM) was tested. Results showed that the $\triangle 6 \mathrm{D}$ mRNA level was enhanced in larvae fed a low $\mathrm{n}-3$ HUFA diet and that this effect remained for 30 days in the resulting juveniles fed the $n-3$ HUFA-restricted juvenile diet. Moreover, a slightly, but significantly, higher DHA content in the polar lipids of pre-conditioned juveniles was measured. Similar results were not found in larvae fed the high HUFA diet or in the resulting juveniles. This indicates that pre-conditioned juveniles could better develop desaturation processes in order to adapt to low dietary HUFA than unconditioned fish. However, the $\triangle 6 \mathrm{D}$ mRNA stimulation was transient in pre-conditioned juveniles, with the effect only being detectable for 30 days. This was interpreted as an adaptation of juveniles to a nutritional environment restricted in $n-3$ HUFA since the low $n-3$ HUFA diet used during juvenile stage $(0.5 \%$ EPA + DHA, \% DM) was close to the n-3 HUFA requirement of sea bass juveniles, which was reported to be $0.7 \% \mathrm{EPA}+\mathrm{DHA}(\% \mathrm{DM})$ by Skalli and Robin (2004). The use of a more restricted $n-3$ HUFA diet for larvae and juveniles led to a persistent enhancement of the $\triangle 6 \mathrm{D}$ mRNA level in juveniles pre-conditioned with a low $n-3$ HUFA diet during larval stage (Vagner et al., 2009). However, this did not lead to an increase in HUFA tissue content in juveniles, contrary to previous observations (Vagner et al., 2007b). In conclusion, it is not clear if the stimulation of the $\triangle 6 \mathrm{D}$ mRNA level by diet is a persistent adaptation at the molecular level or if it is an acclimation to the nutritional environment of juveniles (Vagner et al., 2007b, 2009). One hypothesis raised is that some molecular adaptations are settled during the larval stage in conditioned larvae, and that these molecular pathways could later be modulated by the nutritional environment during the juvenile stage to control HUFA tissue content (Vagner et al., 2007b, 2009).

3.1.3.2. Variation with the $\triangle 6 D$ substrate. Several studies reported that the degree of nutritional modulation of $\Delta 6 \mathrm{D}$ enzymatic activity by VO diets depends on the dietary ratio of $18: 3 n-3 / 18: 2 n-6$, both of which are $\Delta 6 \mathrm{D}$ enzyme substrates (Padley et al., 1986; Tocher et al., 2001a, 2002; Izquierdo et al., 2008). Maximal enzyme efficiency is reached at particular levels of substrate availability (Bell et al., 2002; Francis et al., 2009). For example, Bell et al. (2002) fed Atlantic salmon (S. salar) a diet in which the added lipid was either $100 \%$ palm oil (PO, $38 \% 18: 1 \mathrm{n}-9$ and $10 \% 18: 2 \mathrm{n}-6$ as $\triangle 6 \mathrm{D}$ enzyme substrates) and $0 \%$ FO, $75 \%$ PO and $25 \%$ FO, 50\% PO and 50\% FO, 25\% PO and 75\% FO, or $0 \% \mathrm{PO}$ and $100 \% \mathrm{FO}$. The results showed a progressive increase in the $\left[1-{ }^{14} \mathrm{C}\right] 18: 3 n-3$ desaturation product (i.e., $18: 4 n-3$ ) with added dietary palm oil. However, only fish fed $100 \%$ palm oil were significantly different from the other three treatments, with a 10 -fold higher activity than fish fed $100 \%$ FO. Nevertheless, when palm oil made up more than $50 \%$ of the dietary lipid, significant reductions in muscle $20: 5 n-3,22: 6 n-3$, and $n-3 / n-6$ FA ratio occurred.

It is well known that $\triangle 6 \mathrm{D}$ enzyme in fish has a higher affinity with $\mathrm{n}-3$ than with $\mathrm{n}-6$ FAs (Section 2.2). Several studies have shown that using a high $18: 3 n-3 / 18: 2 n-6$ ratio in the diet leads to greater $\Delta 6 \mathrm{D}$ activity (Bell et al., 1997, 2001; Tocher et al., 1997, 2000, 2001a, 2002; Li et al., 2008). For example, borage oil, which contains only $\gamma$-LNA (i.e., $\gamma-18: 3 n-3$ ), leads to total desaturation products that are 2-fold higher than those found with other VOs in Atlantic salmon (Tocher et al., 1997). More recently, a study on salmonids found that palm oil (which has a very high $18: 3 n-3 / 18: 2 n-6$ ratio) led to hepatic FA desaturation activities $~ 10$-fold higher in fish fed a diet where the lipid was $100 \%$ palm oil compared to in those fed a diet containing 100\% FO (Bell et al., 2002). However, increases in FA desaturation activities were only 2.4- to 2.8-fold higher in fish fed diets where all FO was replaced by various VOs (Bell et al., 1997, 2001; Tocher et al., 1997, 2000, 2001a,b, 2002). All these results are in accordance with a more recent study indicating that a high $18: 3 n-3$ / $18: 2 \mathrm{n}-6$ ratio up-regulated $\Delta 6 \mathrm{D}$ gene expression (Li et al., 2008). The $\triangle 6 \mathrm{D}$ mRNA level was significantly higher in Siganus canaliculatus fed a diet containing perilla oil as the sole lipid source (rich in $\alpha$-LNA $[\alpha-18: 3 n-3])$ compared to those fed a diet containing safflower oil as the sole lipid source (rich in LA [18:2n-6]). The $\triangle 6 \mathrm{D}$ mRNA levels were nevertheless significantly higher in both these groups of fish than in those fed FO as the sole lipid source (Li et al., 2008).

An excess of $18: 3 n-3$ in the diet could block $\triangle 6 \mathrm{D}$ gene transcription (Izquierdo et al., 2008). Complete inhibition of $\Delta 6 \mathrm{D}$ gene expression was observed in gilthead seabream larvae fed a diet in which FO was totally replaced by linseed oil (Izquierdo et al., 2008). Other studies also showed that an excess of $18: 3 n-3$ could inhibit $\triangle 6 \mathrm{D}$ enzymatic activity, preventing desaturation of $18: 2 n-6$ (Bell et al., 1993). Reduced $\Delta 6 \mathrm{D}$ activity was measured in sea bass hepatocytes and in Atlantic salmon enterocytes when fish were fed linseed oil containing up to $56 \% 18: 3 n-3$ with the $18: 3 n-3 / 18: 2 n-6$ ratio over 3 (Padley et al., 1986; Tocher et al., 2002; Zheng et al., 2005a,b). Previously, Tocher et al. (2002) found no evidence of dietary $18: 2 n-6$ desaturation products in either the liver or intestinal tissue of Atlantic salmon fed a diet with linseed oil while the stimulation of desaturation pathways was revealed by an increase in $18: 4 n-3$ products.

Previous studies in salmonids suggested that too high a level of $18: 2 n-6$ in VOs may also inhibit the desaturation of $18: 3 n-3$ (Ruyter et al., 2000; Tocher et al., 2001a,b). A higher 18:2n-6/18:3n-3 ratio in FO than in a linseed oil diet led to a higher quantity of 18:2n-6 desaturation products in Atlantic salmon hepatocytes due to the lower percentage of the competing 18:3n-3 (Ruyter et al., 2000). This is in accordance with the higher $18: 2 n-6$ desaturation products measured in rainbow trout and sea bass when the level of competing 18:3n-3 FA was low in the diet (Bell et al., 1996; Vagner et al., 2007b, 2009). However, it is important to note that Tocher et al. (1997) found increased amounts of $18: 3 n-3$ desaturation products in hepatocytes from Atlantic salmon fed diets that contained high levels of $n-6$ FA. This was explained by the higher affinity of $\Delta 6 \mathrm{D}$ with $\mathrm{n}-3 \mathrm{FA}$ than with n-6 FA (Tocher et al., 1997).

The $18: 3 n-3$ fatty acid could also compete with $24: 5 n-3$ for the $\Delta 6 \mathrm{D}$ (Fig. 1). This could explain why no desaturation products were found in hepatocytes of Atlantic salmon fed linseed oil diet (18:3n-3) despite a $18: 3 n-3 / 18: 2 n-6$ dietary ratio of nearly two (Ruyter et al., 2000 ). This ratio should normally favour the conversion of $18: 3 n-3$ into HUFA, but the ratio of $20: 5 n-3 / 18: 3 n-3$ was two. Thus, the $20: 5 n-3$ can easily be converted to $24: 5 n-3$, which competes with $18: 3 n-3$ for the $\Delta 6 \mathrm{D}$. The $24: 5 n-3$ newly formed is then converted at the expense of 18:3n-3 (Ruyter et al., 2000). These results are in accordance with those of Yu and Sinnhuber (1976), who demonstrated that more unmetabolized radioactivity was recovered when $18: 3 n-3$ was the substrate than when $18: 2 n-6$ was used. 
Ruyter et al. (2000) hypothesized that competition between the $\triangle 6 \mathrm{D}$ substrates could partly explain the HUFA deficiency observed in tissues of fish fed high VO dietary contents, while VOs provide sufficient C18 FA substrates for the $\triangle 6 \mathrm{D}$ and thus for potential conversion to 20:5n-3 [EPA] and 22:6n-3 [DHA] (Ruyter et al., 2000; Torstensen et al., 2000; Tortensen et al., 2005; Bell et al., 2001, 2002, 2003a,b; Tocher et al., 2001a,b, 2002, 2003a,b; Mourente and Dick, 2002; Seiliez et al., 2003; Zheng et al., 2005a,b; Francis et al., 2007, 2009; Vagner et al., 2007a,b, 2009; Izquierdo et al., 2008). Despite the increase in gene expression and $\Delta 6 \mathrm{D}$ activity as well as the increase in $\triangle 6 \mathrm{D}$ desaturation products in fish fed $\mathrm{VO}$, an excessively high dietary content of C18 FA may prove counterproductive when the aim is to maximize in vivo $\mathrm{n}-3$ HUFA production (Francis et al., 2009). Furthermore, these HUFA deficiencies could also be a consequence of low activities during subsequent steps of elongation and desaturation by $\Delta 5 \mathrm{D}$. Deficiencies in these steps have been measured in turbot and sea bream cell lines (Ghioni et al., 1999; Tocher and Ghioni, 1999). It is also important to note that, while the $\Delta 6 \mathrm{D}$ has been described as the rate-limiting enzyme in the FA biosynthetic pathways (Brenner, 1981a,b), HUFA synthesis can also be limited by $\triangle 5 \mathrm{D}$ and elongase since these enzymes are also under nutritional and environmental regulation (Zheng et al., 2004b, 2005a,b; Francis et al., 2007; Izquierdo et al., 2008).

\subsubsection{Mechanisms involved in the nutritional modulation of $\triangle 6 D$}

It has remained unclear whether $\Delta 6 \mathrm{D}$ nutritional modulation is due more to desaturation product reduction or to increased substrate supply, or if both are involved. Some authors demonstrated that the rate of C18 FA desaturation was more strongly regulated by the competition between C18 FA substrates for $\triangle 6 \mathrm{D}$ than by DHA (Ruyter et al., 2000; Francis et al., 2007). However, Tocher et al. (2002) speculated that this rate of desaturation is a direct result of product reduction rather than an increased supply of precursors. Conversely, other authors concluded that both product reduction and increased substrate supply were factors determining hepatocyte FA desaturation activity (Christiansen et al., 1991; Horrobin, 1991; Tocher et al., 2003a,b). Further investigation is required to identify the mechanisms involved.

In mammals, FA desaturases are known to be regulated by two transcription factors: Sterol Regulatory Element Binding Protein-1 (SREBP-1) and Peroxisome Proliferator-Activated Receptors (PPARs) (for a review, see Nakamura and Nara, 2002, 2003). In mammals, desaturases are unique in that they are the only genes whose transcription is activated by both SREBP- 1 and PPARs (Nakamura and Nara, 2002, 2003).

SREBP-1 presents two subforms in mammals: SREBP-1a in differentiating cells and SREBP-1c in cells already differentiated. In humans, SREBP-1c would induce $\triangle 6 \mathrm{D}$ gene transcription binding to SRE (Sterol Regulatory Element), a promoter region located on the $\Delta 6 \mathrm{D}$ gene (Horton et al., 2002; Matsuzaka et al., 2002). This promoter would also be responsible for the inhibition of $\triangle 6 \mathrm{D}$ gene transcription by HUFA (Nara et al., 2002). Over-expression of SREBP-1 increases $\triangle 6 \mathrm{D}$ gene transcription in mice, while disruption of the SREBP-1 gene reduces $\Delta 6 \mathrm{D}$ gene transcription (Matsuzaka et al., 2002).

PPARs are nuclear receptors that have three isoforms in mammals, birds, and amphibians: $\alpha, \beta$ or $\delta$, and $\gamma$ (Dreyer et al., 1992). In mammals, each isoform is a product of a separate gene and has a distinct tissue distribution (Desvergne and Wahli, 1999; Escher et al., 2001; Hihi et al., 2002). PPAR $\alpha$ represents the predominant hepatic isoform in mammals. It controls target genes involved in the intestinal absorption of HUFA and in FA $\beta$-oxidation that occurs in liver mitochondria and peroxisomes (Gulick et al., 1994). It is also involved in hepatic FA biosynthesis. PPAR $\beta$ is involved in keratinocyte differentiation in which lipid metabolism is very active (Tan et al., 2002). PPAR $\gamma$ plays a role in adipogenesis, stimulating adipocyte differentiation and the induction of lipogenic enzymes (Gregoire et al.,
1998; Zhang et al., 2006). PPAR ligands are lipids such as HUFA (EPA, DHA, and AA) and CLA, but they also include eicosanoids, prostaglandins, and leukotrienes (Forman et al., 1997; Kliewer et al., 1997; Krey et al., 1997; Leaver et al., 2005). The ligand-PPAR complex binds to the retinoic acid $X$ receptor (RXR), forming a heterodimer. This heterodimer then binds to the regulation zone of target genes involved in FA $\beta$-oxidation, called the Peroxisome Proliferator Response Element (PPRE) or PPAR response zone, to module their transcription (Schoonjans et al., 1996). This FA $\beta$-oxidation would then lead to a HUFA requirement, which will activate $\triangle 6 \mathrm{D}$ gene transcription indirectly. PPAR would also have a direct action on $\triangle 6 \mathrm{D}$ gene transcription (Tang et al., 2003). However, the delay in desaturase activation related to the activation of enzymes involved in FA $\beta$-oxidation observed in mammal hepatocytes would indicate that $\triangle 6 \mathrm{D}$ gene transcription is mainly controlled by the indirect action of PPAR (Tan et al., 2002; Tang et al., 2003). However, the precise mechanisms involved are not well known.

Concerning fish, partial cDNAs for two distinct PPAR $\beta$-like proteins have been described from zebrafish (Robinson-Rechavi et al., 2001). In pufferfish (Fugu rubripes), a single homolog of the human PPAR $\beta$ and $\gamma$ genes and two homologs of the human PPAR $\alpha$ gene were suggested (Maglish et al., 2003). In Atlantic salmon, a complete cDNA sequence similar to PPAR $\gamma$ has been isolated (Andersen et al., 2000). However, this species may contain up to five PPAR genes, and their precise roles have not been clearly defined (Leaver et al., 2005). Recent work has revealed that three species of marine fish, plaice (Pleuronectes platessa), gilthead seabream, and sea bass, share gene sequences of PPAR $\alpha, \beta$, and $\gamma$ that are homologous to those of mammals, with phylogenetic characteristics similar to the mammalian PPAR counterparts; this would also suggest similar molecular roles (Boukavala et al., 2004; Leaver et al., 2005). In contrast, PPAR $\gamma$ is expressed more widely in seabream and plaice tissues than in mammals whereas PPAR $\alpha$ and $\beta$ expression profiles are similar to those in mammals. As in mammals, PPARs in these species bind to a variety of natural PPRE.

Recent studies suggested the involvement of PPARs in the modulation of $\triangle 6 \mathrm{D}$ gene transcription in fish (Kennedy et al., 2006; Vagner et al., 2009). PPAR $\alpha$ and $\beta$ mRNA levels were significantly higher in sea bass larvae fed a diet low in $n-3$ HUFA $(0.3-0.5 \%$ $\mathrm{EPA}+\mathrm{DHA}, \% \mathrm{DM})$ compared to those fed a diet higher in $\mathrm{n}-3$ HUFA (0.7-3.7\% EPA + DHA, \% DM; Vagner et al., 2009). Furthermore, the PPAR $\beta$ mRNA stimulation was maintained when the resulting juveniles were fed a very low $n-3$ HUFA diet (0.3\% EPA + DHA, \% $\mathrm{DM})$. This is in accordance with the significantly higher $\triangle 6 \mathrm{D}$ mRNA levels measured in these larval and juvenile groups at the same time. These concomitant increases of $\triangle 6 \mathrm{D}$ and PPAR mRNA levels in larvae and juveniles suggested that PPAR could be partly involved in the nutritional modulation of $\triangle 6 \mathrm{D}$ gene transcription in larval and juvenile sea bass (Vagner et al., 2009). Although the PPAR $\gamma$ mRNA level was not significantly higher in larvae fed a diet deficient in $n-3$ HUFA, it was significantly higher in the resulting juveniles. This suggests that PPAR $\gamma$ could have a role in the stimulation of $\triangle 6 \mathrm{D}$ gene transcription measured at the same time (Vagner et al., 2009). Conversely, PPAR mRNA levels were not significantly higher in larvae fed a low $n-3$ HUFA diet from 0.7 to $0.8 \%$ EPA + DHA (\% DM) or in the resulting juveniles, even though significantly higher $\triangle 6 \mathrm{D}$ mRNA levels were measured in the larvae and juveniles (Vagner et al., 2007a,b, 2009). These results led to the hypothesis that $\triangle 6 \mathrm{D}$ gene transcription in sea bass could be stimulated by PPAR when drastic nutritional conditions occurred, and that above a certain dietary HUFA threshold, other mechanisms like those observed in mammals may be implicated, such as SREBP-1 (Vagner et al., 2007a,b, 2009).

This possible involvement of PPAR in the nutritional modulation of $\triangle 6 \mathrm{D}$ gene transcription in fish has also been reported in Atlantic salmon (Kennedy et al., 2006). Higher $\triangle 6 \mathrm{D}$ and PPAR $\alpha$ and $\gamma$ mRNA levels as well as higher HUFA synthesis in liver, red muscle, and white 
muscle were measured in fish fed a low-oil diet with a highly conjugated LA (CLA) content (Kennedy et al., 2006). This could indicate a role for ligand activation of PPAR $\alpha$ by CLA. This is in accordance with the activation in mammals of $\triangle 6 \mathrm{D}$ gene transcription by LA $(18: 2 n-6)$, which act as high-affinity ligands for PPAR $\alpha$ (MoyaCamarena et al., 1999). In contrast, in fish fed high-oil diets, $\Delta 6 \mathrm{D}$ expression and HUFA synthesis were repressed, even when similar amounts of CLA were present (Kennedy et al., 2006). This could indicate a possible role of SREBP-1 proteins in $\triangle 6 \mathrm{D}$ repression (Kennedy et al., 2006). Consequently, these authors hypothesized that transcription factors equivalent to mammalian PPAR $\alpha$ and SREBP-1c are directly involved in regulating $\triangle 6 \mathrm{D}$ in fish via a feedback mechanism (Kennedy et al., 2006).

\subsection{Environmental modulation of $\Delta 6 D$ gene expression and enzymatic activity}

In addition to nutritional factors, environmental factors such as temperature and salinity have been demonstrated to mediate $\triangle 6 \mathrm{D}$ gene expression and enzymatic activity in teleosts (Bell et al., 1997; Tocher et al., 2000, 2004; Zheng et al., 2005a,b).

\subsubsection{Effect of temperature}

It is well documented that temperature influences the degree of FA saturation in fish membranes (Ninno et al., 1974; de Torrengo and Brenner, 1976; Hazel, 1995; Ruyter et al., 2003; Tocher et al., 2004). Several studies demonstrated that FA in phospholipids are less saturated in fish exposed to low temperatures than in fish exposed to high temperatures so that membrane fluidity is maintained (Sellner and Hazel, 1982; Cossins, 1983; Cossins and Bowler, 1987; Tiku et al., 1996). For example, at $5{ }^{\circ} \mathrm{C}$, the percentage of $16: 0$ was lower and the percentage of 22:6n-3 was higher in the total lipid fraction of salmon hepatocytes than at $12{ }^{\circ} \mathrm{C}$, indicating a tendency for a higher production of $22: 6 n-3$ from $\left[1-{ }^{14} \mathrm{C}\right] 20: 4 \mathrm{n}-3$ at low temperatures (Moya-Falcón et al., 2006). This phenomenon is known as homeoviscous adaptation, and it ensures that membrane function is unaltered during changes in water temperature (Sinesky, 1974; Robertson and Hazel, 1999). However, this notion as related to fish was questioned by Sargent et al. (2002), who considered that the intrinsic structure of DHA was resistant to temperature variation and that its abundance of phospholipid ensures membrane fluidity, whatever the temperature.

Several studies reported that the increase in the degree of FA unsaturation at low temperatures is related to changes in both desaturase and elongase capacities (Ninno et al., 1974; de Torrengo and Brenner, 1976; Schünke and Wodtke, 1983; Hagar and Hazel, 1985; Wodtke and Cossins, 1991). It has been shown in several freshwater fish species that the $\Delta 6 \mathrm{D}$ activity decreases when temperature increases (Ninno et al., 1974; de Torrengo and Brenner, 1976; Schünke and Wodtke, 1983; Hagar and Hazel, 1985; Tocher et al., 2004). For example, $\Delta 6 \mathrm{D}$ activity was higher in common carp kept at $10{ }^{\circ} \mathrm{C}$ than in those kept at $30^{\circ} \mathrm{C}$ (Schünke and Wodtke, 1983). The $\triangle 6 \mathrm{D}$ activity was also higher in enterocytes and hepatocytes of rainbow trout kept at $5{ }^{\circ} \mathrm{C}$ or $7{ }^{\circ} \mathrm{C}$ than in trout kept at $20^{\circ} \mathrm{C}$ or $15{ }^{\circ} \mathrm{C}$ respectively (Hagar and Hazel, 1985; Tocher et al., 2004). Catfish (Pimelodus maculatus) kept at $14-15{ }^{\circ} \mathrm{C}$ had higher liver microsomal desaturation activities for oleic, LA, and $\alpha$-LNA than did fish kept at 29-30 ${ }^{\circ} \mathrm{C}$ (de Torrengo and Brenner, 1976). Similarly, $\Delta 6 \mathrm{D}$ activities in liver microsomes have been shown to be 2 -fold higher at $16{ }^{\circ} \mathrm{C}$ than at $30^{\circ} \mathrm{C}$ (Ninno et al., 1974). Furthermore, a variation in the $\Delta 6 \mathrm{D}$ activity of catfish has been observed for a temperature variation of $\pm 2{ }^{\circ} \mathrm{C}$ (de Torrengo and Brenner, 1976).

De Torrengo and Brenner (1976) demonstrated that the induction timing of $\triangle 6 \mathrm{D}$ gene transcription could depend on temperature. When catfish acclimated to $28^{\circ} \mathrm{C}$ were shifted to $18{ }^{\circ} \mathrm{C}, \Delta 6 \mathrm{D}$ activity initially decreased one day after transfer, probably due to a kinetic effect, but subsequently increased one week after transfer, presumably due to the induction of gene transcription. However, when a temperature increase occurred, the response time for gene transcription inhibition was only one day (de Torrengo and Brenner, 1976).

The interaction between water temperature and diet in the regulation of FA desaturation has been investigated in several studies (Ruyter et al., 2003; Tocher et al., 2004; Vagner et al., 2007a,b). The cultured hepatocytes of Atlantic salmon fed with increasing amount of soybean oil in the diet (substrates: $18: 3 n-3,18: 2 n-6$ and $24: 5 n-3$ ) demonstrated more desaturation products when fish were reared at $5{ }^{\circ} \mathrm{C}$ than at $12{ }^{\circ} \mathrm{C}$ (Ruyter et al., 2003). In rainbow trout acclimatized to 7,11 , or $15^{\circ} \mathrm{C}$ and fed for four weeks on diets in which FO was replaced in a graded manner by crude palm oil, both water temperature and diet had significant effects on 18:3n-3 desaturation. The effects of the graded levels of dietary palm oil on desaturation activities were most clearly observed at $11^{\circ} \mathrm{C}$ in both hepatocytes and enterocytes (Tocher et al., 2004). Unlike the results from these studies, similar $\triangle 6 \mathrm{D}$ mRNA levels were measured at low $\left(16{ }^{\circ} \mathrm{C}\right)$ and high $\left(22^{\circ} \mathrm{C}\right)$ temperatures in sea bass larvae fed a diet deficient in $n-3$ HUFA (0.7\% EPA + DHA, \% DM), although these values were significantly higher than $\triangle 6 \mathrm{D}$ mRNA levels of fish fed a diet rich in n-3 HUFA (2.2\% EPA + DHA, \% DM; Vagner et al., 2007a,b). This observation in marine fish is in accordance with the very low expression and functional activity of $\triangle 6 \mathrm{D}$ with nutritional modulation recorded in marine fish tissues compared to freshwater fish and salmonids (Tocher et al., 2006a,b; González-Rovira et al., 2009).

Some studies have shown that the influence of temperature on variations in desaturation activity depends on the tissue (Tocher et al., 2004; Skalli et al., 2006). For example, the highest desaturation activity was observed at $7{ }^{\circ} \mathrm{C}$ in enterocytes and at $11{ }^{\circ} \mathrm{C}$ in hepatocytes in rainbow trout (Tocher et al., 2004).

It is assumed that the adaptive change in the desaturation activity of microsomes with changes in environmental temperature does not greatly modify the final FA composition of the fish since increased $\triangle 6 \mathrm{D}$ activity at low temperatures was associated with decreased yield of the desaturation reaction (de Torrengo and Brenner, 1976; Tocher et al., 2004).

\subsubsection{Effect of salinity}

The regulation of desaturation pathways for HUFA synthesis by salinity has been particularly well demonstrated in relation to parrsmolt transformation of salmonids (Bell et al., 1997; Tocher et al., 2000; Fonseca-Madrigal et al., 2006).

In Atlantic salmon, $\Delta 6 \mathrm{D}$ gene expression increased significantly around the time of seawater transfer; it was at its lowest point during the seawater phase, irrespective of diet (Zheng et al., 2005a). Similarly, the euryhaline teleost $S$. canaliculatus showed a 1.56 -fold higher $\Delta 6 \mathrm{D}$ gene expression in liver at salinities of $10 \mathrm{ppt}$ than at $32 \mathrm{ppt}$ (Li et al., 2008), suggesting that the transcriptional control of $\triangle 6 \mathrm{D}$ gene expression is involved in the regulation of the HUFA biosynthetic pathway by ambient salinities.

These results are in accordance with the significant increase in $\triangle 6 \mathrm{D}$ activities measured around seawater transfer independent of fish diet ([FO or VO]; Bell et al., 1997; Tocher et al., 2000, 2003b; Fonseca-Madrigal et al., 2006), with a subsequent reduction in activity after transfer to seawater (Bell et al., 1997). However, activities measured were higher in fish fed VO (up to 3-fold) than in those fed FO (Bell et al., 1997; Fonseca-Madrigal et al., 2006). This is in accordance with $\mathrm{Li}$ et al. (2008), who showed that the higher $\Delta 6 \mathrm{D}$ gene expression in S. canaliculatus measured at $10 \mathrm{ppt}$ than at $32 \mathrm{ppt}$ was significantly higher in fish fed a HUFA-free diet (containing safflower and perilla oils as lipid sources) than in those fed a HUFArich diet (containing FO as the lipid source). Despite differences in $\triangle 6 \mathrm{D}$ activities between fish fed FO and fish fed VO, the levels of AA, EPA, and DHA appeared to converge at seawater transfer in salmonids (Bell et al., 1997). This could indicate that these HUFA 
must reach a genetically predetermined level that must be achieved to allow seawater transition to occur, and that this level was attained despite the differences in dietary FA composition (Bell et al., 1997).

Salinity-mediated variations of $\triangle 6 \mathrm{D}$ gene expression and activity are in accordance with measurements made in salmonids hepatocytes: HUFA synthesis was higher during the freshwater phase, peaked around seawater transfer, and declined again in the seawater phase (Tocher et al., 2003b; Zheng et al., 2005a; Fonseca-Madrigal et al., 2006). This increase in HUFA synthesis and the regulation of $\triangle 6 \mathrm{D}$ gene expression are part of the pre-adaptive processes of smoltification, which prepare the fish for the marine environment (Folmar and Dickhoff, 1980) and may contribute to the increased tissue HUFA levels observed before transfer to seawater (Sheridan

A.

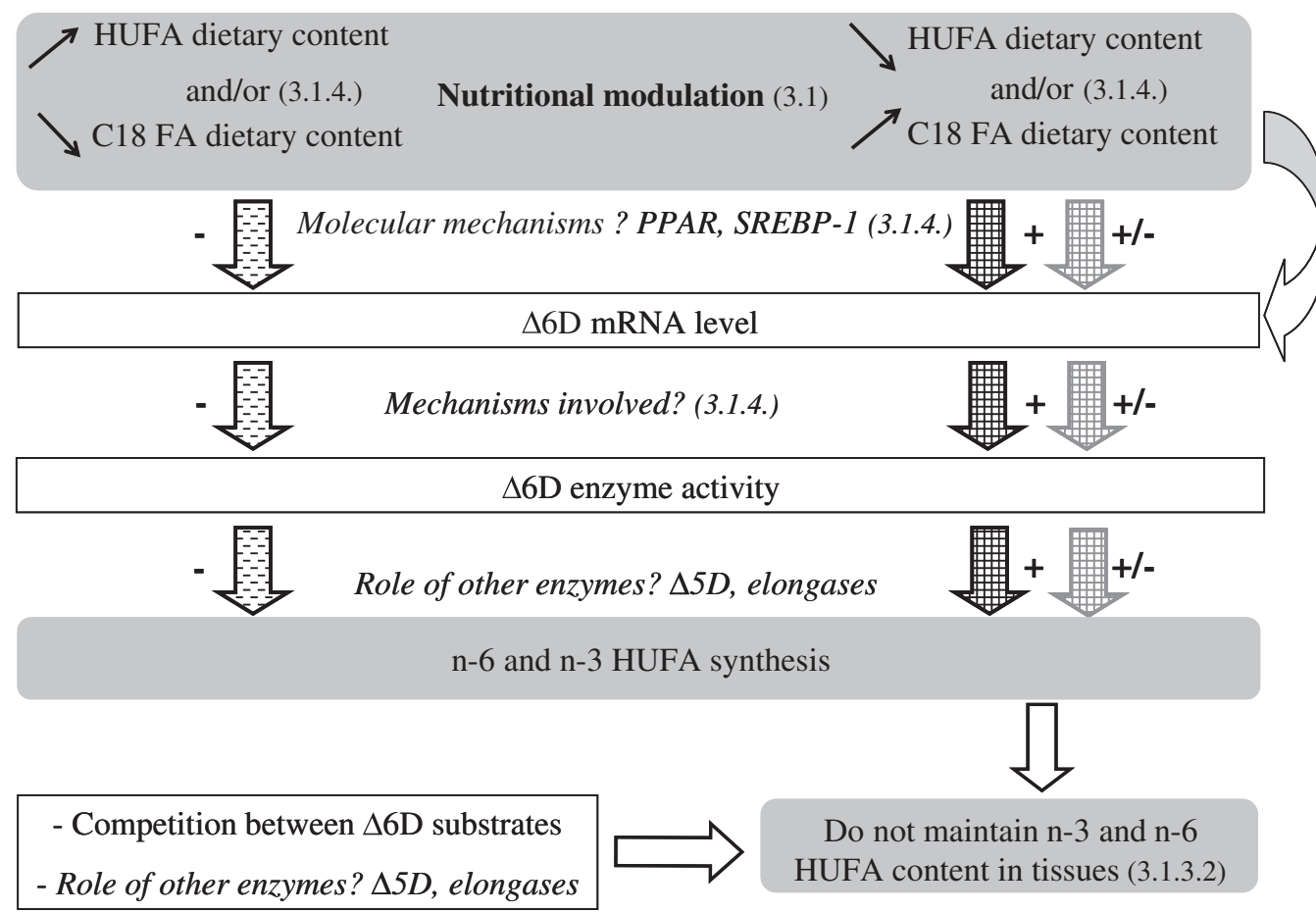

Could be partly controlled by PPAR (3.1.4)

B.

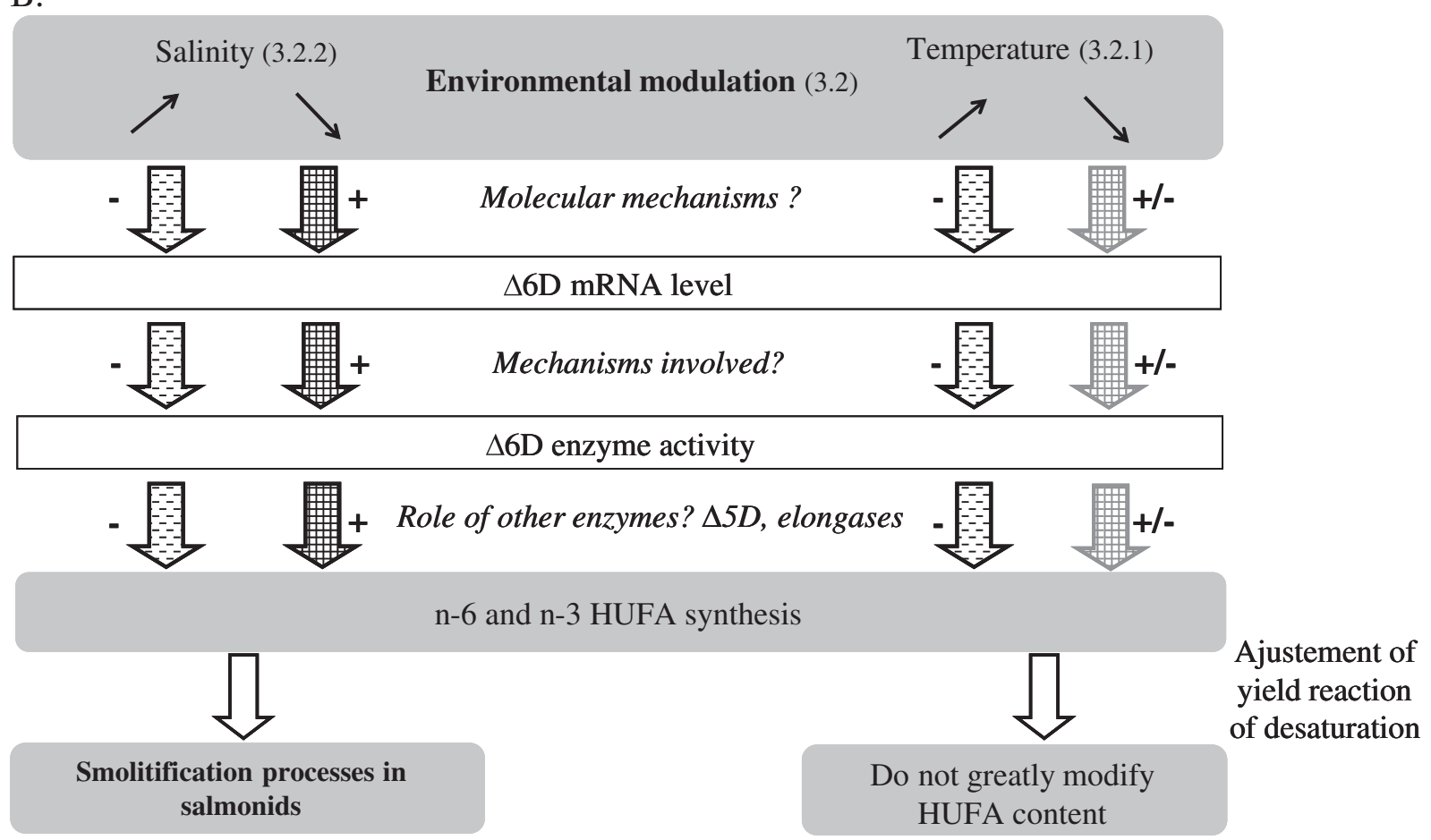

Fig. 3. Summary of nutritional (A) and environmental (B) modulation of $\Delta 6 \mathrm{D}$ in teleosts reviewed in this paper. Black arrows indicate the modulation in freshwater fish, while grey arrows indicate a more barely modulation in marine fish. Numbers in brackets report to the chapter in the review. In italic are indicated the obscure points requiring complementary studies. 
et al., 1985; Li and Yamada, 1992). In addition, masu salmon that had undergone smoltification but were maintained in freshwater on the same diets underwent a desmoltification process that was accompanied by a return to a "freshwater type" lipid composition ( $\mathrm{Li}$ and Yamada, 1992). This indicates that lipid metabolism could be modified in response to ambient salinity changes (Li and Yamada, 1992). Several studies have described the importance of HUFA in adaptation to salinity changes: a diet deficient in HUFA can cause reduced ionic permeability in brush border membranes in trout (Di Constanzo et al., 1983) and morphological changes in the gills of turbot (Bell et al., 1985), and can affect the activity of a number of ion pumps and membrane-bound enzymes, including $\mathrm{Na}^{+} / \mathrm{K}^{+}$-ATPase (Spector and Yorek, 1985; Salem et al., 1988; Gerbi et al., 1994). Moreover, HUFA are substrates for eicosanoid synthesis and prostaglandins, which are known to mediate fluid and electrolyte fluxes in fish gills and kidneys and are therefore important in adaptation to salinity changes (Brown and Bucknall, 1986; Mustafa and Srivastava, 1989). It is important to note that although $\triangle 5 \mathrm{D}$ and elongase gene expression also showed temporal variation, it was not correlated with the changes in the HUFA biosynthetic pathway activity (Zheng et al., 2005a). These data suggest that the regulatory mechanisms of HUFA biosynthesis in response to seasonal effects, including smoltification, were primarily due to the regulation of $\Delta 6 \mathrm{D}$ expression. This is consistent with $\Delta 6 \mathrm{D}$ being the rate-limiting step in the pathway (Brenner, 1981a,b).

Further studies are required to clarify the regulatory process of $\Delta 6 \mathrm{D}$ gene expression by salinity. It is known that a large number of endocrine systems, such as cortisol, angiotensin II, growth hormone, and insulin-growth factor, are affected during salinity adaptation. $\Delta 6 \mathrm{D}$ gene expression could thus be modulated by salinity through some related mechanisms, such as those influencing hormone production and metabolism, interactions of hormones and their target tissues, and signal transduction (Li et al., 2008).

\subsubsection{Effect of other environmental factors}

Because photoperiod is the primary environmental cue controlling smoltification, some studies have investigated its influence on HUFA biosynthetic activity during parr-smolt transformation in Atlantic salmon (Bell et al., 1997; Tocher et al., 2000). However, nothing is known about the potential mechanisms involving the regulation of $\Delta 6 \mathrm{D}$ by photoperiod (Zheng et al., 2005a).

The nutritional and environmental modulations of $\triangle 6 \mathrm{D}$ gene expression and enzymatic activity in teleosts reported in this paper are summarized in Fig. 3.

\section{Conclusion}

This review showed that fish desaturases are similar to those of mammals and that a high percentage of intraspecific similarity has been described between $\Delta 6 \mathrm{D}$ and $\triangle 5 \mathrm{D}$. The first fish desaturase that was characterized was the bifunctional $\Delta 5 / \Delta 6$ enzyme in zebrafish. However, other fish desaturases have been found to be unifunctional (in cod) or have a major desaturase activity with a residual desaturate capacity in the other position. Furthermore, fish desaturases have been found to have preferences for $\mathrm{n}-3$ substrates; this is important in the context of the substitution of FOs with VOs in the diets of cultured fish.

The evidence presented clearly shows that $\Delta 6 \mathrm{D}$ is under nutritional and environmental regulation in freshwater fish, and it functions to control lipid metabolism and thus maintains cell membrane functionality. $\Delta 6 \mathrm{D}$ gene expression and enzymatic activity were higher in fish fed a diet with high VO content (low HUFA and high C18 content) than in those fed diets with high FO content (high HUFA and low C18 content). This increased activity compensates for the HUFA deficiency in VO, irrespective of whether fish are in seawater or freshwater. Moreover, $\Delta 6 \mathrm{D}$ gene expression and enzymatic activity are stimulated at low temperatures, thus maintaining the fluidity and consequently the functionality of cell membranes. $\Delta 6 \mathrm{D}$ gene expression and enzymatic activity are also stimulated at low salinity, thus they play an important role in salinity adaptation during parr-smolt transformation in salmonids.

Some of these nutritional and environmental modulations of $\Delta 6 \mathrm{D}$ may occur in marine fish, although conflicting data exist. The $\Delta 6 \mathrm{D}$ enzyme appears to be barely functional in marine fish. This could be explained by a low expression of the $\Delta 6 \mathrm{D}$ gene or by the involvement of genetic, environmental, or hormonal factors.

The nutritional modulation observed seems not enough to maintain HUFA tissue content in freshwater or marine fish. This could be due to competition between C18 FA substrates for $\triangle 6 \mathrm{D}$, or to deficiencies in subsequent HUFA biosynthesis steps, such as elongation and/or desaturation at the delta-5 position. Therefore, it seems necessary that all enzymes involved in the HUFA biosynthesis be considered concomitantly in order to better understand its regulation and the precise role played by $\triangle 6 \mathrm{D}$. These kinds of studies will give new and crucial information for aquaculture feed development.

It could also be interesting to investigate the effects of environmental variables other than temperature and salinity, such as photoperiod, ambient oxygen availability, or water $\mathrm{pH}$, on $\Delta 6 \mathrm{D}$ gene expression and enzymatic activity. This would allow a better understanding of the effect of controlled parameters on HUFA biosynthetic pathways, and thus on fish flesh quality in aquaculture.

This review showed that while many studies have investigated the nutritional modulation of $\Delta 6 \mathrm{D}$, little is known about the molecular mechanisms involved in its regulation. The stimulation of $\triangle 6 \mathrm{D}$ mRNA levels by the nutritional environment seems to be partly controlled by PPARs, but the precise molecular mechanisms involved remain unclear. It is still unclear whether $\triangle 6 \mathrm{D}$ nutritional modulation is due more to desaturation product reduction or to increased substrate supply, or if both are involved. Finally, nothing is known about how temperature and salinity affect $\Delta 6 \mathrm{D}$ gene expression. Further investigations are required in these fields.

\section{Acknowledgements}

Research done by both authors are cited in this review and were supported by grants received from Ifremer (Institut Français pour la Recherche et l'Exploitation de la Mer) and INRA (Institut National de Recherche Agronomique), and work was performed at the Ifremer Institute of Brest, France. Both authors are grateful to C. Cahu, D. Mazurais, J. Person-Le Ruyet, J.H. Robin, and J.L. Zambonino for their scientific assistance, to N. Le Bayon, E. Débruyères, H. Le Delliou, M.M. Le Gall, C. Huelvan, P. Quazuguel, and A. Sévère for their technical assistance, and to $C$. Audet for linguistic revision.

\section{References}

Aki, T., Shimada, Y., Inagaki, K., Higashimoto, H., Kawamoto, S., Shiget, S., Ono, K., Suzuki, O., 1999. Molecular cloning and functional characterisation of rat $\Delta 6$ fatty acid desaturase. Biochem. Biophys. Res. Commun. 255, 575-579.

Andersen, O., Eijsink, V.G., Thomassen, M., 2000. Multiple variants of the peroxisome proliferator-activated receptor gene from the marine flatfish, the plaice (Pleuronectes platessa). Mar. Environ. Res. 46, 75-79.

Argyropoulou, V., Kalogeropoulos, N., Alexis, M.N., 1992. Effect of dietary lipids on growth and tissue fatty acid composition of grey mullet (Mugil cephalus). Comp. Biochem. Physiol. A 101, 129-135.

Bell, M.V., Henderson, R.J., Pirie, B.J.S., Sargent, J.R., 1985. Effects of dietary polyunsaturated fatty acid deficiencies on mortality, growth and gill structure in the turbot (Scophthalmus maximus, Linnaeus). J. Fish Biol. 26, 181-191.

Bell, J.G. Dick, J.R., Vicar, M.C. Sargent, J.R., Thompson, K.D., 1993. Dietary sunflower, linseed and fish oils affect phospholipid fatty acid composition, development of cardiac lesions, phospholipase activity and eicosanoid production in Atlantic salmon. Prostaglandins Leukot. Essent. Fatty Acids 49, 665-673. 
Bell, J.G., Ashton, I., Secombes, C.J., Weitzel, B.R., Dick, J.R., Sargent, J.R., 1996. Dietary lipid affects phospholipid fatty acid compositions, ecosanoid production and immune function in Atlantic salmon (Salmo salar). Prostaglandins Leukot. Essent. Fatty Acids 54, 173-182.

Bell, J.G., Tocher, D.R., Farndale, B.M., Cox, D.I., McKinney, R.W., Sargent, J.R., 1997. The effect of dietary lipid on polyunsaturated fatty acid metabolism in Atlantic salmon (Salmo salar) undergoing parr-smolt transformation. Lipids 32, 515-525.

Bell, J.G., McEvoy, J., Tocher, D.R., McGhee, F., Campbell, P.J., Sargent, J.R., 2001. Replacement of fish oil with rapeseed oil in diets of Atlantic salmon (Salmo salar) affects tissue lipid compositions and hepatocyte fatty acid metabolism. J. Nutr. 131, 1535-1543.

Bell, J.G., Henderson, R.J., Tocher, D.R., McGhee, F., Dick, J.R., Porter, A., Smullen, R., Sargent, J.R., 2002. Substituting fish oil with crude palm oil in the diet of Atlantic salmon (Salmo salar) affects tissue fatty acid composition and hepatic fatty acid metabolism. J. Nutr. 132, 222-230.

Bell, J.G., McGhee, F., Campbell, P.J., Sargent, J.R., 2003a. Rapeseed oil as an alternative to marine fish oil in diets of post-smolt Atlantic salmon (Salmo salar): changes in flesh fatty acid composition and effectiveness of subsequent fish oil "wash out". Aquaculture 218, 515-528

Bell, J.G., Tocher, D.R., Henderson, R.J., Dick, J.R., Crampton, V.O., 2003b. Substitution of marine fish oil with linseed and rapeseed oils in diets for Atlantic salmon (Salmo salar) affects muscle fatty acid composition: restoration of fatty acid composition following "wash out" with fish oil. J. Nutr. 133, 2793-2801.

Boukavala, E., Antonopoulou, E., Favre-Kery, L., Diez, A., Bautista, J.M., Leaver, M.J., Tocher, D.R., Krey, G., 2004. Molecular characterization of three peroxisome proliferator-activated receptors from the sea bass (Dicentrarchus labrax). Lipids 39 (11), 1085-1092.

Brenner, R.R., 1974. The oxidative desaturation of unsaturated fatty acids in animals. Mol. Cell. Biochem. 3, 41-52.

Brenner, R.R., 1981a. Early effects of essential fatty acid deficiency on structure and enzymatic activity of rat liver microsomes. Prog. Lipid Res. 20, 41-47.

Brenner, R.R., 1981b. Nutritional and hormonal factors influencing desaturation of essential fatty acids in animals. Prog. Lipid Res. 20, 41-47.

Brown, J.A., Bucknall, R.M., 1986. Antidiuretic and cardiovascular actions of $\mathrm{PGE}_{2}$ in the rainbow trout Salmo gairdneri. Gen. Comp. Endocrinol. 61, 330-337.

Buzzi, M., Henderson, R.J., Sargent, J.R., 1996. The desaturation and elongation of linolenic acid and ecosapentaenoic acid by hepatocytes and liver microsomes from rainbow trout (Oncorhynchus mykiss) fed diets containing fish oil or olive oil. Biochem. Biophys. Acta 1299, 235-244.

Buzzi, M., Henderson, R.J., Sargent, J.R., 1997. Biosynthesis of docosahexaenoic acid in trout hepatocytes proceeds via 24-carbon intermediates. Comp. Biochem. Physiol. 116B, 263-267.

Cao, J.M., Blond, J.P., Juaneda, P., Durand, G., Bezard, J., 1995. Effects of low levels of dietary fish oils on fatty acid desaturation and tissue fatty acids in obese and lean rats. Lipids 30, 825-832.

Cho, H.P., Nakamura, M.T., Clarke, S.D., 1999a. Cloning, expression and nutritional regulation of the human $\Delta 6$ desaturase. J. Biol. Chem. 274, 471-477.

Cho, H.P., Nakamura, M.T., Clarke, S.D., 1999b. Cloning expression and nutritional regulation of the human D5 desaturase. J. Biol. Chem. 274, 37335-37339.

Christiansen, E.N., Lund, J.S., Rørtveit, T., Rustan, A.C., 1991. Effects of dietary n-3 and n-6 fatty acids on fatty acid desaturation in rat liver. Biochim. Biophys. Acta 1082, 57-62.

Clandinin, M.T., Foot, M., Robson, L., 1983. Plasma membrane: can its structure and function be modulated by dietary fat? Comp. Biochem. Physiol. 76B, 335-339.

Cossins, A.R., 1983. Adaptative responses of fish membranes to altered environmental temperature. Biochem. Soc. Trans. 11, 332-333.

Cossins, A.R., Bowler, K., 1987. Temperature Biology of Animals. Chapman \& Hall, London, pp. 156-203.

D'Andrea, S., Guillou, H., Jan, S., Catheline, D., Thibault, J.N., Bourriel, M., Rioux, V., Legrand, P., 2002. The same rat $\Delta 6$-desaturase not only acts on 18 - but also on 24 carbon fatty acids in very long chain polyunsaturated fatty acid biosynthesis. Biochem. J. 364, 49-55.

De Antueno, R.J., Knickle, L.C., Smith, H., Elliot, M.L., Allen, S.J., Nwaka, S., Winther, M.D., 2001. Activity of human D5 and D6 desaturases on multiple $n-3$ and $n-6$ polyunsaturated fatty acids. FEBS Lett. 509, 77-80.

De Torrengo, M.P., Brenner, R.R., 1976. Influence of environmental temperature on the fatty acid desaturation and elongation activity of fish (Pimelodus maculatus) liver microsomes. Biochim. Biophys. Acta 424, 36-44.

Delarue, J., Matzinger, O., Binnert, C., Schneiter, P., Chiolero, R., Tappy, L., 2003. Fish oil prevents the adrenal activation elicited by mental stress in healthy men. Diab. Metab. 29 (3), 289-295.

Delarue, J., LeFoll, C., Corporeau, C., Lucas, D., 2004. N-3 long chain polyunsaturated fatty acids: a nutritional tool to prevent insulin resistance associated to type 2 diabetes and obesity? Reprod. Nutr. Dev. 44 (3), 289-299.

Desvergne, B., Wahli, W., 1999. Peroxisome proliferator-activated receptors: nuclear control of metabolism. Endocr. Rev. 20, 649-688.

Di Constanzo, G., Duportail, G., Florents, A., Leray, C., 1983. The brush border membrane of trout intestine: influence of its lipid composition on ion permeability, enzyme activity and membrane fluidity. Mol. Physiol. 4, 279-290.

Dreyer, C., Krey, G., Keller, H., Givel, F., Helftenbein, G., Wahli, W., 1992. Control of the peroxisomal $\beta$-oxidation pathway by a novel family of nuclear hormone receptors. Cell 68, 879-887.

Eder, K., Slomma, N., Becker, K., 2002. Trans-10, cis-12 conjugated linoleic acid suppresses the desaturation of linoleic and $\alpha$-linoleic acids in HepG2 cells. J. Nutr. $132,1115-1121$.

Escher, P., Braissant, O., Basu-Modak, S., Michalik, L., Wahli, W., Desvergne, B., 2001. Rat PPAR: quantitative analysis in adult rat tissues and regulation in fasting and refeeding. Endocrinology 142, 4195-4202.
Folmar, L.C., Dickhoff, W.W., 1980. The parr-smolt transformation (smoltification) and seawater adaptation in salmonids: a review of selected literature. Aquaculture 21 , $1-37$.

Fonseca-Madrigal, J., Karalazos, V., Campbell, P.J., Bell, J.G., Tocher, D.R., 2005. Influence of dietary palm oil on growth and tissue fatty acid compositions, and fatty acid metabolism in liver and intestine in rainbow trout (Onchorhynchus mykiss). Aquacult. Nutr. 11, 241-250.

Fonseca-Madrigal, J., Bell, J.G., Tocher, D.R., 2006. Nutritional and environmental regulation of the synthesis of highly unsaturated fatty acids and fatty-acid oxidation in Atlantic salmon (Salmo salar L.) enterocytes and hepatocytes. Fish Physiol. Biochem. 32, 317-328.

Forman, B.M., Chen, J., Evans, R.M., 1997. Hypolipidemic drugs, polyunsaturated fatty acids, and eicosanoids are ligands for peroxisome proliferator-activated receptors alpha and delta. Proc. Natl. Acad. Sci. U. S. A. 94, 4312-4317.

Francis, D.S., Turchini, G.M., Jones, P.L., De Silva, S.S., 2007. Dietary lipid source modulates in vivo fatty acid metabolism in the freshwater fish, Murray cod (Maccullochella peelii peelii). J. Agric. Food Chem. 55, 1582-1591.

Francis, D.S., Peters, D.J., Turchini, G.M., 2009. Apparent in vivo delta-6 desaturase activity, efficiency, and affinity are affected by total dietary C18 PUFA in the freshwater fish Murray cod. J. Agric. Food Chem. 57, 4381-4390.

Garg, M., Sebokova, E., Thomson, A., Clandini, M., 1988. Delta-6 desaturase activity in liver microsomes of rats fed diets enriched with cholesterol and/or omega-3 fatty acids. Biochem. J. 249, 351-356.

Gerbi, A., Zerouga, M., Debray, M., Durand, G., Chanez, C., Bourre, J.M., 1994. Effect of fish oil diet on fatty acid composition of phospholipids on brain membranes and on kinetic properties of $\mathrm{Na}+, \mathrm{K}+$-ATPase isoenzymes of weaned and adult rats. J. Neurochem. 62, 1560-1569.

Ghioni, C., Tocher, D.R., Bell, M.V., Dick, J.R., Sargent, J.R., 1999. Low C18 to C20 fatty acid elongase activity and limited conversion of stearidonic acid, 18:4n-3, to eicosapentaenoic acid, $20: 5 n-3$, in a cell line from the turbot, Scophthalmus maximus. Biochim. Biophys. Acta 1437, 170-181.

González-Rovira, A., Mourente, G., Zheng, X., Tocher, D.R., Pendon, C., 2009. Molecular and functional characterization and expression analysis of a delta-6 fatty acyl desaturase cDNA of European sea bass (Dicentrarchus labrax L.). Aquaculture 298, 90-100.

Gregoire, F.M., Smas, C.M., Sul, H.S., 1998. Understanding adipocyte differentiation. Physiol. Rev. 78, 783-809.

Gulick, T., Cresci, S., Caira, T., Moore, D.D., Kelly, D.P., 1994. The peroxisome proliferators-activated receptor regulates mitochondrial fatty acid oxidative enzyme gene expression. Proc. Natl. Acad. Sci. U. S. A. 91, 11012-11016.

Hagar, A.F., Hazel, J.R., 1985. Changes in desaturase activity and the fatty acid composition of microsomal membranes from liver tissue of thermally-acclimating rainbow trout. J. Comp. Physiol. B 156, 35-42.

Hastings, N., Agaba, M., Tocher, D.R., Leaver, M.J., Dick, J.R., Sargent, J.R., Teale, A.J., 2001. A vertebrate fatty acid desaturase with $\Delta 5$ and $\Delta 6$ activities. Proc. Natl. Acad. Sci. U. S. A. 98, 14304-14309.

Hastings, N., Agaba, M.K., Tocher, D.R., Zheng, X., Dickson, C.A., Dick, J.R., Teale, A.J., 2005. Molecular cloning and functional characterization of fatty acyl desaturase and elongase cDNAs involved in the production of eicosapentaenoic and docosahexaenoic acids from $\alpha$-linolenic acid in Atlantic salmon (Salmo salar). Mar. Biotechnol. 6, 463-474.

Hazel, J.R., 1995. Effects of temperature on the structure and metabolism of cell membranes in fish. Am. J. Physiol. 246, 460-470.

Henderson, R.J., Tocher, D.R., 1987. Lipid composition and biochemistry of freshwater fish. Prog. Lipid Res. 26, 281-347.

Henderson, R.J., Park, M.T., Sargent, J.R., 1995. The desaturation and elongation of 14Clabelled polyunsaturated fatty acids by pike (Esox lucius L.) in vivo. Fish Physiol. Biochem. 14, 223-235.

Hihi, A.K., Michalik, L., Wahli, W., 2002. PPARs: transcriptional effectors of fatty acids and their derivatives. Cell. Mol. Life Sci. 59, 790-798.

Holman, R.T., 1986. Control of polyunsaturated fatty acids in tissue lipids. J. Am. Coll. Nutr. 5, 183-211.

Horrobin, D.F., 1991. Interactions between $n-3$ and $n-6$ essential fatty acids (EFAs) in the regulation of cardiovascular disorders and inflammation. Prostaglandins Leukot. Essent. Fatty Acids 44, 127-131.

Horton, J.D., Goldstein, J.L., Brown, M.S., 2002. SREBPs: activators of the complete program of cholesterol and fatty acid synthesis in the liver. J. Clin. Invest. 109, 1125-1131.

Izquierdo, M.S., Robaina, L., Juárez-Carrillo, E., Oliva, V., Hernandez-Cruz, C.M., Afonso, J.M., 2008. Regulation of growth, fatty acid composition and delta-6 desaturase expression by dietary lipids in gilthead seabream larvae (Sparus aurata). Fish Physiol. Biochem. 34, 117-127.

Kajikawa, M., Yamato, K.T., Kohzu, Y., Nojiri, M., Sakuradani, E., Shimizu, S., Sakai, Y. Fukuzawa, H., Ohyama, K., 2004. Isolation and characterization of D6-desaturase, an ELO-like enzyme and D5-desaturase from the liverwort Marchantia Polymorpha and production of arachidonic and ecosapentaenoic acids in the methylotrophic yeast Pichia Pastoris. Plant Mol. Biol. 54, 335-352.

Kanazawa, A., Teshima, S.I., Ono, K., 1978. Relationship between essential fatty acid requirements of aquatic animals and the capacity for bioconversion of linoleic acid to highly unsaturated fatty acids. Comp. Biochem. Physiol. 63B, 295-298.

Kennedy, S.R., Campbell, P.J., Porter, A., Tocher, D.R., 2005. Influence of dietary conjugated linoleic acid (CLA) on lipid and fatty acid composition in liver and flesh of Atlantic salmon (Salmo salar). Comp. Biochem. Physiol. B 141, 168-178.

Kennedy, S.R., Leaver, M.J., Campbell, P.J., Zheng, X., Dick, J.R., Tocher, D.R., 2006. Influence of dietary oil content and conjugated linoleic acid (CLA) on lipid metabolism enzyme activities and gene expression in tissues of Atlantic salmon (Salmo salar). Lipids 41 (5), 423-436. 
Kliewer, S.A., Sundseth, S.S., Jones, S.A., Brown, P.J., Wisely, G.B., Koble, C.S., Devchand, P., Wahli, W., Willson, T.M., Lenhard, J.M., Lehmann, J.M., 1997. Fatty acids and eicosanoids regulate gene expression through direct interactions with peroxisome proliferator-activated receptor $\gamma$ and promotes adipocyte differentiation. Cell 83 813-819.

Krey, G., Braissant, O., L'Horset, F., Kalkhoven, E., Perroud, M., Parker, M.G., Wahli, W. 1997. Fatty acids, eicosanoids, and hypolipidemic agents identified as ligands of peroxisome proliferators-activated receptors by coactivator-dependant receptor ligand assay. Mol. Endocrinol. 11, 779-791.

Lands, W.E.M., 1991. Dose-response relationships for $\omega 3 / \omega 6$. In: Simopoulos, A.P. Kifer, R.R., Martin, R.E., Barlow, S.M. (Eds.), Effects, in health effects of $\omega 3$ polyunsaturated fatty acids in seafoods. Karger, Basel, pp. 177-194.

Lauritzen, L., Hansen, H.S., Jorgensen, M.H., Michaelsen, K.F., 2001. The essentiality of long chain $\mathrm{n}-3$ fatty acids in relation to development and function of the brain and retina. Prog. Lipid Res. 40, 1-94.

Leaver, M.J., Boukouvala, E., Antonopoulou, E., Diez, A., Favre-Krey, L., Ezaz, M.T., Tocher, D.R Batista, J.M., Krey, G., 2005. Three peroxisomal proliferator-activated receptor (PPAR) isotypes from each of two species of marine fish. Endocrinology 146, 3150-3162.

Leaver, M.J., Tocher, D.R., Obach, A., Jensen, L., Henderson, R.J., Porter, A.R., Krey, G., 2006. Effect of dietary conjugated linoleic acid (CLA) on lipid composition, metabolism and gene expression in Atlantic salmon (Salmo salar) tissues. Comp. Biochem. Physiol. A 145, 258-267.

Leger, C., Fremont, L., Boudon, M., 1981. Fatty acid composition of lipids in the trout-I. Influence of dietary fatty acids on the triglyceride fatty acid desaturation in serum, adipose tissue, liver, white and red muscle Comp. Biochem. Physiol. 69B, 99-105.

Li, H.O., Yamada, J., 1992. Changes of the fatty acid composition in smolts of masu salmon (Oncorhynchus masou) associated with desmoltification and seawate transfer. Comp. Biochem. Physiol. 103A, 221-226.

Li, Y., Hu, C., Zheng, Y., Xia, X., Xu, W., Wang, S., Chen, W., Sun, Z., Huang, J., 2008. The effects of dietary fatty acids on liver fatty acid composition and delta-6 desaturase expression differ with ambient salinities in Siganus canaliculatus. Comp. Biochem. Physiol. B 151, 183-190.

Maglish, J.M., Caravella, J.A., Lambert, M.H., Willson, T.M., Moore, J.T., Ramamurthy, L. 2003. The first completed genome sequence from a teleost fish (Fugu rubripes) add significant diversity to the nuclear receptor superfamily. Nucleic Acids Res. 31 4051-4058.

Matsuzaka, T., Shimano, H., Yahagi, N., Amemiya-Kudo, M., Yoshikawa, T., Hasty, A.H., Tamura, Y. Osuga, J. I, Okazaki, $\mathrm{H}$, Iizuka, Y Takahashi, A Sone, H. Gotoda, Ishibashi, S., Yamada, $N$, 2002. Dual regulation of mouse $\Delta 5$ and $\Delta 6$-desaturase gene expression by SREBP-1 and PPAR $\alpha$. J. Lipid Res. 43, 107-114.

McMurchie, E.J., 1988. Dietary lipids and the regulation of membrane fluidity and function. In: Aloia, R.C., Curtain, C.C., Gordon, L.M. (Eds.), Physiological Regulation of Membrane Fluidity. Alan R. Liss, New York, pp. 189-337.

Merrill, A.H., Schroeder, J.J., 1993. Lipid modulation of cell function. Annu. Rev. Nutr. 13, 529-559.

Mourente, G., Dick, J.R., 2002. Influence of partial substitution of dietary fish oil by vegetable oils on the metabolism of $\left[1-{ }^{14} \mathrm{C}\right] 18: 3 n-3$ in isolated hepatocytes of European sea bass (Dicentrarchus labrax L.). Fish Physiol. Biochem. 26, 297-308.

Mourente, G., Tocher, D.R., 1994. In vivo metabolism of $\left[1-{ }^{14} \mathrm{C}\right]$ linolenic acid $(18: 3 n-3)$ and $\left[1-{ }^{14} \mathrm{C}\right]$ eicosapentaenoic acid $(20: 5 n-3)$ in marine fish: Time-course of the desaturation/elongation pathway. Biochim. Biophys. Acta 1212, 109-118.

Mourente, G., Good, J.E., Bell, J.G., 2005a. Partial substitution of fish oil with rapeseed, linseed and olive oils in diets for European sea bass (Dicentrarchus labrax L.) Effects on flesh fatty acid composition, plasma prostaglandins E2 and F2 $\alpha$, immune function and effectiveness of a fish oil finishing diet. Aquacult. Nutr. 11, 25-40.

Mourente, G., Dick, J.R., Bell, J.G., Tocher, D.R., 2005b. Effect of partial substitution of dietary fish oil by vegetable oils on desaturation and oxidation of [1-14C]18:3n-3 and $[1-14 C] 20: 5 n-3$ in hepatocytes and enterocytes of European sea bass (Dicentrarchus labrax L.). Aquaculture 248, 173-186.

Moya-Camarena, S.Y., Van den Heuvel, J.P., Blanchard, S.G., Leesnitzer, L.M., Belury, M.A 1999. Conjugated linoleic acid is a potent naturally occurring ligand and activato of PPAR $\alpha$. J. Lipid Res. 40, 1426-1433.

Moya-Falcón, C., Hvattumb, E., Tranc, T.N., Thomassen, M.S., Skorved, E.J., Ruyter, B. 2006. Phospholipid molecular species, $\beta$-oxidation, desaturation and elongation of fatty acids in Atlantic salmon hepatocytes: effects of temperature and 3-thia fatty acids. Comp. Biochem. Physiol. B 145, 68-80.

Mustafa, T., Srivastava, K.C., 1989. Prostaglandins (eicosanoids) and their role in ectothermic organisms. Adv. Comp. Environ. Physiol. 5, 157-207.

Nakamura, M.T., Nara, T.Y., 2002. Gene regulation of mammalian desaturases. Biochem. Soc. Trans. 30 (6), 1076-1079.

Nakamura, M.T. Nara, T.Y., 2003. Essential fatty acid synthesis and its regulation in mammals. PLEFA $68,145-150$.

Nara, T.Y., He, W.S., Tang, C., Clarke, S.D., Nakamura, M.T., 2002. The E-box like stero regulatory element mediates the suppression of human delta-6 desaturase gene by highly unsaturated fatty acids. Biochem. Biophys. Res. Commun. 296, 111-117.

Ninno, R.E., de Torrengo, M.A.P., Castuma, J.C., Brenner, R.R., 1974. Specificity of 5- and 6-fatty acid desaturases in rat and fish. Biochim. Biophys. Acta 360, 124-133.

Olsen, R.E., Ringo, E., 1992. Lipids of arctic charr, Salvelinus alpinus (L.) II. Influence of dietary fatty acids on the elongation and desaturation of linoleic and linolenic acid. Fish Physiol. Biochem. 9, 393-399.

Owen, J.M., Adron, J.W., Middleton, C., Cowey, C.B., 1975. Elongation and desaturation of dietary fatty acids in turbot (Scophtalamus maximus L.), and rainbow trout (Salmo gairdnerii Rich.). Lipids 10 (9), 528-531.

Padley, F.B., Gunstone, F.D., Harwood, J.L., 1986. Occurrence and characteristics of oils and fats. In: Gunstone, F.D., Harwood, J.L. Padley, F.B. (Eds.), The lipid handbook. Chapman and Hall, London, pp. 49-170.
Peters, J.M., Park, Y., Gonzales, F.., Pariza, M.W., 2001. Influence of conjugated linoleic acid on body composition and target gene expression in peroxisome proliferatoractivated receptor $\alpha$-Null mice. Biochim. Biophys. Acta 1533, 233-241.

Pike, I.H., 2005. Eco-efficiency in aquaculture: global catch of wild fish used in aquaculture. Int. Aquafeed 8, 38-39.

Rivers, J.P.W., Sinclair, A.J., Crawford, M.A., 1975. Inability of the cat to desaturate essential fatty acids. Nature $258,171-173$.

Robertson, J.C., Hazel, J.R., 1999. Influence of temperature and membrane lipid composition on the osmotic water permeability of teleost gills. Physiol. Biochem. Zool. 72 (5), 623-632.

Robinson-Rechavi, M., Marchand, O., Escriva, H., Bardet, P.L., Zelus, D., Hughes, S. Laudet, V., 2001. Euteleost fish genomes are characterized by expansion of gene families. Genome Res. 11 (5), 781-788

Ruyter, B., Røsjø, C., Måsøval, K., Einen, O., Thomassen, M.S., 2000. Influence of dietary $n-3$ fatty acids on the desaturation and elongation of $\left[1-{ }^{14} \mathrm{C}\right] 18: 2 \mathrm{n}-6$ and $\left[1-{ }^{14} \mathrm{C}\right]$ 18:3n-3 in Atlantic salmon hepatocytes. Fish Physiol. Biochem. 23, 151-158.

Ruyter, B., Røsjø, C., Grisdale-Helland, B., Rosenlund, G., Obach, A., Thomassen, M.S 2003. Influence of temperature and high dietary linoleic acid content on esterification, elongation, and desaturation of PUFA in Atlantic salmon hepatocytes. Lipids 38 (8), 833-840.

Salem, N., Shingu, T., Kim, H.Y., Hullin, F., Bougnoux, P., Karanian, J.W., 1988. In Karnovsky, M.L., Bolis, L., Leaf, A. (Eds.), Biological membranes: abberrations in membrane structure and function. Alan R. Liss, New York, pp. 319-333.

Santigosa, E., Geay, F., Tonon, T., Corcos, L., Cahu, C., Zambonino-Infante, J., Mazurais, D., 2010. Cloning, tissue expression analysis and functional characterisation of two $\Delta 6$-desaturase variants of sea bass (Dicentrarchus labrax, L.). Mar. Biotechnol. doi:10.1007/s10126-010-9264-4.

Sargent, J.R., Tacon, A., 1999. Development of farmed fish: a nutritionally necessary alternative to meat. Proc. Nutr. Soc. 58, 377-383.

Sargent, J., Bell, J.G., Bell, M.V., Henderson, R.J., Tocher, D.R., 1995. Requirement criteria for essential fatty acids. J. Appl. Ichthyol. 11, 183-198.

Sargent, J., McEvoy, L., Estevez, A., Bell, G., Bell, M., Henderson, J., Tocher, D.R., 1999. Lipid nutrition of marine fish during early development: current status and future directions. Aquaculture 179, 217-229.

Sargent, J.R., Tocher, D.R., Bell, J.G., 2002. The lipids, third edition. In: Halver, J.E., Hardy, R.W. (Eds.), Fish Nutrition. Academic Press, London, pp. 182-259.

Sayanova, O.V., Beaudoin, F., Michaelson, L.V., Shewry, P.R., Napier, J.A., 2003. Identification of Primula fatty acid $\Delta 6$-desaturases with $\mathrm{n}-3$ substrate preferences. FEBS Lett. 542, 100-104.

Schoonjans, K., Staels, B., Auwerx, J., 1996. The peroxisome proliferator-activated receptors (PPARS) and their effects on lipid metabolism and adipocyte differentiation. Biochem. Biophys. Acta 1302, 93-109.

Schünke, M., Wodtke, E, 1983. Cold-induced increase of $\Delta 9$ - and $\Delta 6$-desaturase activities in endoplasmic membranes of carp liver. Biochim. Biophys. Acta 734 70-75.

Seierstad, S.L., Seljeflot, I., Johansen, O., Hansen, R., Haugen, M., Rosenlund, G., Frøyland, L., Arnsesn, H., 2005. Dietary intake of differently fed salmon; the influence on markers of human atherosclerosis. Eur. J. Clin. Invest. 35, 52-59.

Seiliez, I., Panserat, S., Kaushik, S., Bergot, P., 2001. Cloning, tissue distribution and nutritional regulation of a delta-6 desaturase-like enzyme in rainbow trout. Comp. Biochem. Physiol. B 130, 83-93.

Seiliez, I., Panserat, S., Corraze, G., Kaushik, S., Bergot, P., 2003. Cloning and nutritional regulation of a $\triangle 6$-desaturase-like enzyme in the marine teleost gilthead seabream (Sparus aurata). Comp. Biochem. Physiol. 135B, 449-460.

Sellner, P.A., Hazel, J.R., 1982. Incorporation of polyunsaturated fatty acids into lipids of rainbow trout hepatocytes. Am. J. Physiol. 243, 223-228.

Sheridan, M.A., Allen, W.V., Kerstetter, T.H., 1985. Changes in the fatty acid composition of steelhead trout, Salmo gairdnerii Richardson, associated with parr-smolt transformation. Comp. Biochem. Physiol. 80B, 671-676.

Simopolous, A.P., 1991. Omega-3 fatty acids in health and disease and in growth and development. Am. J. Clin. Nutr. 54, 438-463.

Sinclair, A.J., McLean, J.G., Monger, E.A., 1979. Metabolism of linoleic acid in the cat. Lipids 14, 932-936.

Sinesky, M., 1974. Homeoviscous adaptation: a homeostatic process that regulates the viscosity of membrane lipids in Escherichia coli. Proc. Natl. Acad. Sci. U. S. A. 71 522-525.

Skalli, A., Robin, J.H., 2004. Requirement of $\mathrm{n}-3$ long chain polyunsaturated fatty acids for European sea bass (Dicentrachus labrax) juveniles: growth and fatty acid composition. Aquaculture 240, 399-415.

Skalli, A., Robin, J.H., Le Bayon, N., Le Delliou, H., Person-Le Ruyet, J., 2006. Impact of essential fatty acid deficiency on tissues' fatty acid composition of European sea bass (Dicentrarchus labrax). Aquaculture 255, 223-232.

Spector, A.A., Yorek, M.A., 1985. Membrane lipid composition and cellular function. J. Lipid Res. 26, 1015-1035.

Stubbs, C.D., Smith, A.D., 1984. The modification of mammalian membrane polyunsaturated fatty acid composition in relation to membrane fluidity and function. Biochim. Biophys. Acta 779, 89-137.

Tacon, A.G., 2004. Use of fish meal and fish oil in aquaculture: a global perspective. Aquat. Resour. Cult. Dev. 1, 3-14.

Takahashi, Y., Kushiro, M., Shinohara, K., Ide, T., 2003. Activity and mRNA levels of enzymes involved in hepatic fatty acid synthesis and oxidation in mice fed conjugated linoleic acid. Biochim. Biophys. Acta 1631, 265-273.

Tan, N.S., Shaw, N.S., Vinckenbosh, N., Liu, P., Yasmin, R., Desvergne, B., Wahli, W., Noy, N., 2002. Selective cooperation between fatty acid binding proteins and peroxisome proliferator-activated receptors in regulating transcription. Mol. Cell. Biol. 22 (14), 5114-5127. 
Tang, C., Cho, H.P., Nakamura, M.T., Clarke, S.D., 2003. Regulation of human D-6 desaturase gene transcription: identification of a functional direct repeat-1 element. J. Lipid Res. 44, 686-694.

Tidwell, J.H., Allan, G.I., 2002. Fish as food: aquaculture's contribution. World Aquacult. $33,44-48$.

Tiku, P.E., Gracey, A.Y., Macartney, A.I., Beynon, R.J., Cossins, A.R., 1996. Cold-induced expression of delta- 9 desaturase in carp by transcriptional and posttranslational mechanisms. Science 271, 815-818.

Tocher, D.R., Ghioni, C., 1999. Fatty acid metabolism in marine fish: low activity of delta-5 desaturation in gilthead sea bream (Sparus aurata) cells. Lipids 34, 433-440.

Tocher, D.R., Bell, J.G., Disk, J.R., Sargent, J.R., 1997. Fatty acyl desaturation in isolated hepatocytes from Atlantic salmon (Salmo salar): stimulation by dietary borage oil containing $\gamma$-linolenic acid. Lipids 32, 1237-1247.

Tocher, D.R., Bell, J.G., Henderson, R.J., McGhee, F., Mitchell, D., Morris, P.C., 2000. The effect of dietary linseed and rapeseed oils on polyunsaturated fatty acid metabolism in Atlantic salmon (Salmo salar) undergoing parr-smolt transformation. Fish Physiol. Biochem. 23, 59-73.

Tocher, D.R., Bell, J.G., MacGlaughlin, P., McGhee, F., Dick, J.R., 2001a. Hepatocyte fatty acid desaturation and polyunsaturated fatty acid composition of liver in salmonids: effects of dietary vegetable oil. Comp. Biochem. Physiol. 130, 257-270.

Tocher, D.R., Agaba, M., Hastings, N., Bell, J.G., Dick, J.R., Teale, A.J., 2001b. Nutritional regulation of hepatocyte fatty acid desaturation and polyunsaturated fatty acid composition in zebrafish (Danio rerio) and tilapia (Oreochromis nilotica). Fish Physiol. Biochem. 24, 309-320.

Tocher, D.R., Fonseca-Madrigal, J., Bell, J.G., Dick, J.R., Henderson, R.J., Sargent, J.R., 2002. Effects of diet containing linseed oil on fatty acid desaturation and oxidation in hepatocytes and intestinal enterocytes in Atlantic salmon (Salmo salar). Fish Physiol. Biochem. 26, 157-170.

Tocher, D.R., Bell, J.G., Dick, J.R., Crampton, V.O., 2003a. Effects of dietary vegetable oil diets on Atlantic salmon hepatocyte fatty acid desaturation and liver fatty acid compositions. Lipids 38, 723-732.

Tocher, D.R., Bell, J.G., McGhee, F., Dick, J.R., Fonseca-Madrigal, J., 2003b. Effects of dietary lipid level and vegetable oil on fatty acid metabolism in Atlantic salmon (Salmo salar) over the entire production cycle. Fish Physiol. Biochem. 29, 193-209.

Tocher, D.R., Fonseca-Madrigal, J., Dick, J.R., Ng, W., Bell, J.G., Campbell, P.J., 2004. Effects of water temperature and diet containing palm oil on fatty acid desturation and oxidation in hepatocytes and intestinal enterocytes of rainbow trout (Onchorhynchus mykiss). Comp. Biochem. Physiol. 137B, 49-63.

Tocher, D., Zheng, X., Schlechtriem, C., Hastings, N., Dick, J., Teale, A., 2006a. Highly unsaturated fatty acid synthesis in marine fish: cloning, functional characterization, and nutritional regulation of fatty acyl $\Delta 6$ desaturase of Atlantic cod (Gadus morhua L.). Lipids 41 (11), 1003-1016.

Tocher, D.R., Dick, J.R., MacGlaughlin, P.M., Bell, J.G., 2006b. Effect of diets enriched in $\Delta 6$ desaturated fatty acids $(18: 3 n-6$ and $18: 4 n-3)$, on growth, fatty acid composition and highly unsaturated fatty acid synthesis in two populations of Arctic charr (Salvelinus alpinus). Comp. Biochem. Physiol. B 144, 245-253.

Torstensen, B.E., Lie, Ø., Frøyland, L., 2000. Lipid metabolism and tissue composition in Atlantic salmon (Salmo salar)-effects of capelin-palm- and oleic acid enriched sunflower oil as dietary lipid sources. Lipids 35, 653-664.
Tortensen, B.E., Bell, J.G., Rosenlund, G., Henderson, R.., Graff, I.E., Tocher, D.R., Lie, Ø., Sargent, J.R., 2005. Tailoring of Atlantic salmon (Salmo salar) flesh lipid composition and sensory quality by replacing fish oil with a vegetable oil blend. J. Agric. Food Chem. 53, 10166-10178.

Turchini, G.M., Francis, D.S., De Silva, S.S., 2006. Fatty acid metabolism in the freshwater fish Murray cod (Maccullochella peelii peelii) deduced by the whole-body fatty acid balance method. Comp. Biochem. Physiol. B 144 (1), 110-118.

Twibell, R.G., Watkins, B.A., Rogers, L., Brown, P.B., 2000. Effects of dietary conjugated linoleic acids on hepatic and muscle lipids in hybrid striped bass. Lipids 35, 155-161.

Ulmann, L., Bouzianne, M., Mimouni, V., Belleville, J., Poisson, J.P. 1992. Relationship between rat liver microsomal $\Delta 6$ - and $\Delta 5$-desaturase activities and fatty acid composition: comparative effects of coconut and salmon oils during protein restriction. J. Nutr. Biochem. 3, 188-193.

Vagner, M., Robin, J.H., Zambonino Infante, J.L., Person-Le Ruyet, J., 2007a. Combined effect of dietary HUFA level and temperature on sea bass (D. labrax) larvae development. Aquaculture 266, 179-190.

Vagner, M., Zambonino Infante, J.L., Robin, J.H., Person-Le Ruyet, J., 2007b. Is it possible to influence European sea bass (Dicentrarchus labrax) juvenile metabolism by a nutritional conditioning during larval stage? Aquaculture 267, 165-174.

Vagner, M., Robin, J.H., Tocher, D.R., Zambonino Infante, J.L. Person-Le Ruyet, J., 2009. Ontogenic effects of early feeding of sea bass (Dicentrarchus labrax) larvae with a range of dietary $n-3$ HUFA levels on the functioning of polyunsaturated fatty acid desaturation pathways. Br. J. Nutr. 101, 1452-1462.

Watanabe, T., 1982. Lipid nutrition in fish. Comp. Biochem. Physiol. 73B, 3-15.

Wodtke, E., Cossins, A.R., 1991. Rapid cold-induced changes in membrane order and delta-9 desaturase activity in endoplasmic reticulum of carp liver: a time-course study of thermal acclimation. Biochim. Biophys. Acta 1064, 343-350.

Yu, T.C., Sinnhuber, R.O., 1976. Growth response of rainbow trout to dietary $\omega 3$ and $\omega 6$ fatty acids. Aquaculture 8, 309-317.

Zhang, F., Lavan, B.E., Gregoire, F.M., 2006. Selective modulators of PPAR- $\gamma$ activity: molecular aspects related to obesity and side-effects. PPAR Res. 2007, 7 (article 32696).

Zheng, X., Seiliez, I., Hastings, N., Tocher, D.R., Panserat, S., Dickson, C.A., Bergot, P., Teale, A.J., 2004a. Characterization and comparison of fatty acyl $\Delta 6$ desaturase cDNAs from freshwater and marine teleost fish species. Comp. Biochem. Physiol. B 139, 269-279.

Zheng, X., Tocher, D.R., Dickson, C.A., Bell, J.G., Teale, A.J., 2004b. Effects of diets containing vegetable oil on expression of genes involved in polyunsaturated fatty acid biosynthesis in liver of Atlantic salmon (Salmo salar). Aquaculture 236, 467-483.

Zheng, X., Torstensen, B.E., Tocher, D.R., Dick, J.R., Henderson, R.J., Bell, J.G., 2005a. Environmental and dietary influences on highly unsaturated fatty acid biosynthesis and expression of fatty acyl desaturase and elongase genes in liver of Atlantic salmon (Salmo salar). Biochim. Biophys. Acta 1734, 13-24.

Zheng, X., Tocher, D.R., Dickson, C.A., Dick, J.R., Bell, J.G., Teale, A.J., 2005b. Highly unsaturated fatty acid synthesis in vertebrates: new insights with the cloning and characterization of a $\Delta 6$ desaturase of Atlantic salmon. Lipids 40, 13-24.

Zheng, X., King, Z., Xu, Y., Monroig, O., Morais, S., Tocher, D.R., 2009. Physiological roles of fatty acyl desaturases and elongases in marine fish: characterisation of cDNAs of fatty acyl $\Delta 6$ desaturase and elovl5 elongase of cobia (Rachycentron canadum). Aquaculture 290, 122-131. 